\title{
Lactoferrin Can Attenuate SARS-CoV-2: An Analysis of Evidential Relations
}

\author{
Furqan Shafqat ${ }^{1}$, Shafeeq Ur Rehman ${ }^{1}$, Kamal Niaz $^{2, *}$
}

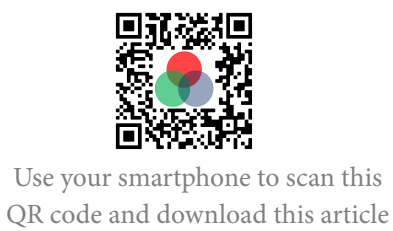

${ }^{1}$ Department of Microbiology, Faculty of Veterinary Science, Cholistan University of Veterinary \& Animal Sciences, Bahawalpur-63100, Pakistan

${ }^{2}$ Department of Pharmacology \& Toxicology, Faculty of Bio-Sciences, Cholistan University of Veterinary \& Animal Sciences, Bahawalpur-63100, Pakistan

\section{Correspondence}

Kamal Niaz, Department of Pharmacology \& Toxicology, Faculty of Bio-Sciences, Cholistan University of Veterinary \& Animal Sciences, Bahawalpur-63100, Pakistan

Email: kamalniaz@cuvas.edu.pk

\section{History}

- Received: Feb 08, 2022

- Accepted: Feb 24, 2022

- Published: Feb 28, 2022

DOI : 10.15419/bmrat.v9i2.727

\section{Check for updates}

\section{Copyright}

( $)$ Biomedpress. This is an openaccess article distributed under the terms of the Creative Commons Attribution 4.0 International license.

\begin{abstract}
Background: Lactoferrin (Lf) has been shown to have antiviral action against a variety of animal and human viruses, particularly deoxyribonucleic acid (DNA) and ribonucleic acid (RNA) viruses. This review aims to summarize the pharmacological activities that lead to the influential role of Lf against SARS-CoV-2. Methods: An all-inclusive search of published articles was carried out to focus on publications related to $L f$ and its biological/pharmacological activities using various literature databases, including the scientific databases Science Direct, Scopus, Web of Science, PubMed, Google Scholar, Google, EMBASE, and Scientific Information (SID). Results: By acting on cell targets, Lf prevents viral attachment, surface accumulation on the host cell, and virus penetration. Lf has shown high antiviral effectiveness across a broad spectrum of viruses, suggesting that it might be used to cure and prevent severe acute respiratory syndrome-coronavirus-2 (SARS-CoV-2). Lf can also attach to viral particles directly, such as hepatitis $C$ virus (HCV), and steer them away from certain sites. LF has a powerful attraction for iron, with a constant of approximately $10^{20}$. Lf capacity to link iron relies on the existence of (minute amounts of) bicarbonate. The bacteriostatic effect of Lf is due to its capability to come together with free iron, which is one of the ingredients necessary for bacterial development. Lf located in neutrophil secondary granules is essential for host defense. Conclusion: Researchers confirmed that Lf activates natural killer (NK) cells in a study. Lf has been shown in certain studies to prevent patronization in pseudovirus severe acute respiratory syndrome (SARS) cases that leads to attenuation of SARS-CoV-2. Lf may decrease inflammation induced by microbial exposure and directly reduce bacterial growth. It is concluded that Lf possesses antibacterial, immunomodulatory, anticancer, antiviral, cytoprotective, and anti-inflammatory activities, which ultimately act as an antiviral against SARS-CoV-2 via various mechanisms.
\end{abstract}

Key words: Lactoferrin, SARS-CoV-2, Antiviral Agents, Anticancer, COVID-19, Infectious

\section{INTRODUCTION}

Lactoferrin (Lf) is a 14-glycan single-chain polypeptide with a molecular weight of $80,000 \mathrm{Da}$, depending on the origin of the species. Human Lf (hLf) is made out of 691 amino acids, and bovine Lf (bLf) is made out of 689 amino acids, with a sequence similarity of $69 \%{ }^{1}$. Each Lf molecule includes two parallel lobes, referred to as the $\mathrm{C}$ - and $\mathrm{N}$-lobes, respectively, according to the $\mathrm{C}$-terminal and $\mathrm{N}$-terminal parts of the molecule. These domains are designated N1, N2, $\mathrm{C} 1$, and $\mathrm{C} 2$, respectively. bLf and hLf have comparable three-dimensional structures, but they are not identical. The second configuration is aided by disulfide bonds in cysteine residues. bLf is only partly iron-saturated $(15-20 \%)$ in its natural state, giving it a brilliant pink hue with varying sharpness depending on the extent of iron saturation. Apo-Lf is iron-exhausted Lf with less than 5\% iron saturation, whereas holo-Lf is iron-saturated $\mathrm{Lf}^{2}$. Apo-Lf is the most common Lf found in breast milk. Lf has a very strong affinity for iron, with a constant of approximately $10^{20}$. The capacity of Lf to bind iron relies on the occurrence of (little quantity of) bicarbonate ${ }^{3}$. The capacity of Lf to bind iron depends on bicarbonate levels, which are negatively impacted by elevated amounts of citrate. On the other hand, citrate can separate from bLf, which is comparable to the in vivo situation in milk. The N-terminus of both hLf and bLf are substantial cationic peptide sequences that contribute to many essential interaction characteristics ${ }^{4}$. A loop in the N1 region with a high affection binding area mediates bacterial lipopolysaccharide (LPS) binding with human and bLf; the C-lobe seems to have poor affection binding regions. The human loop is 28-34 amino acids long, whereas the bovine loop is $17-41$ amino acids long ${ }^{5}$. Due to biological activities, Lf has evolved in various species, including humans. It has been evaluated for a long time. Lf correlates with an iron deficiency linked to bacteria directly, which can impact viruses and parasites. In addition to its protective properties against bacteria, Lf 
also has immunomodulatory effects on immature immune systems. Peptides derived from limited Lf proteolysis, which may occur when Lf is consumed, have been found to retain the majority of the Lf protective qualities, sometimes to a greater extent ${ }^{6}$.

The bacteriostatic effect of Lf combines with that of free iron, which is one of the components needed for bacterial development ${ }^{7}$. Escherichia coli (E. coli) and other iron-dependent bacteria cannot thrive if they do not have enough iron ${ }^{8}$. On the other hand, Lf may serve as an iron supply, encouraging the growth of bacteria that need less iron, such as Lactobacillus sp. or Bifidobacterium sp., which are normally regarded as beneficial bacteria ${ }^{9}$. The bactericidal properties of Lf have also been discovered. The effects of bLf and hLf on the immune system have been studied in a variety of ways. Despite conflicting evidence, Lf seems to have both immunomodulatory and immunostimulatory characteristics ${ }^{10}$. The ability of Lf to bind endotoxin is believed to be important in immunomodulation. The quantity of immune system activation is decreased by binding bacterially generated endotoxin to Lf. This mechanism may avoid overstimulation, which may occur during a condition such as sepsis ${ }^{11}$. Several antibacterial, antimicrobial, and immunomodulatory characteristics have been ascribed to Lf throughout the 1970s and 1980s. Nevertheless, it was not until 1994 that Bezault et al. ${ }^{\mathbf{1 2}}$ presented convincing evidence of hLf anticancer action in mouse models of fibrosarcoma and melanoma. Injections of hLf into the peritoneal cavity, in particular, have been demonstrated to prevent solid tumor development and lung metastasis, independent of how quickly the protein absorbs iron. Several studies have shown that Lf can combat cancer by activating natural killer (NK) cells. Zang et al. ${ }^{13}$ found that employing a methyltransferase blocker to restore hLf gene transcription reduced cancer cell growth and metastasis in an oral squamous cell carcinoma system. Due to their great selectivity for cancer cells and minimal toxicity for normal cells, antimicrobial peptides are also being used in several novel cancer therapies. hLf, bLf, and their related peptides have been investigated and confirmed to play an important role in cancer prevention and therapy due to their comparable cell selectivity ${ }^{\mathbf{1 1}}$.

The antiviral activity of Lf was found much later, although much data have been collected since then, as shown by the significant investigations of Van der Strate et al. ${ }^{\mathbf{1 4}}$. Lf has only been proven to be crucial in avoiding viral infection in a few cases. On the other hand, Lf has an inhibitory impact on a wide variety of viruses ${ }^{15}$. This group includes a variety of enveloped viruses, such as herpes simplex virus (HSV) 1 and 2, human cytomegalovirus, human immunodeficiency virus (HIV), hepatitis B virus (HBV), hepatitis $\mathrm{C}$ virus (HCV), respiratory syncytial virus (RSV), hantavirus, and four naked viruses, rotavirus, poliovirus, adenovirus, and enterovirus $71^{16}$. Both hLf and bLf have inhibitory effects, which are mediated not only by adhering Lf but also, in certain cases, by enzymatic fragments of the molecule, as observed in HSV, cytomegalovirus, adenovirus, and rotavirus ${ }^{17}$. Endoplasmic reticulum (ER) stress inhibition is related to the cytoprotective effect of Lf. Hepatic phosphorylation of eukaryotic initiation factor 2 (p-eIF2) and phosphorylation of nuclear factor kappa-light-chain-enhancer of activated B cells ( $\mathrm{p}$ $\mathrm{NF}-\kappa \mathrm{B}$ ) were significantly higher in $\mathrm{ob} / \mathrm{ob}$ mice than in Lf-treated ob/ob mice. This implies that Lf therapy may reduce ER stress caused by hepatosteatosis ${ }^{18}$. Due to its cytoprotective properties, Lf has been found to minimize ER stress and autophagy formation in injured hepatocytes. It stimulates the upregulation of hypoxia-inducible factor-1 alpha/vascular endothelial growth factor (HIF-l $\alpha /$ VEGF) to aid in hepatic activity recovery ${ }^{19}$. Recent research revealed that Lf has a cytoprotective impact on the survival of human umbilical vein endothelial cells (HUVECs) that had been subjected to $\mathrm{H}_{2} \mathrm{O}_{2}$-induced oxidative damage using the 3-(4,5-dimethylthiazol-2-yl)-2,5-diphenyl2H-tetrazolium bromide (MTT) test ${ }^{20}$.

According to the study, Lf may decrease inflammation induced by microbial exposure and directly reduce bacterial growth. Lf therapy inhibits Helicobacter pylori-induced gastritis, LPS-induced gut mucosal viability, endotoxemia, and mortality caused by systemic E. coli or LPS exposure, according to animal research $^{21}$. Lf may decrease inflammation by reducing the production of proinflammatory cytokines such as tumor necrosis factor-alpha (TNF- $\alpha$ ), interleukin $1 \beta$ (IL-1 $\beta$ ), and IL-6, according to in vitro and in vivo investigations in mononuclear cells and mice ${ }^{22}$. The capability of Lf to attach molecules that connect to the Toll-like receptor (TLR) signaling pathway, which is essential for the subsequent host inflammatory response to microbial invasion, may be the primary mechanism behind this impact ${ }^{23}$.

The ability of Lf to suppress pseudotyped severe acute respiratory syndrome (SARS-CoV) with an IC50 of $0.7 \mathrm{M}$ is very relevant to the current research. Human coronavirus is most often linked with severe acute respiratory syndrome coronavirus-2 (SARS-CoV-2), which causes coronavirus disease 2019 (COVID$19)^{24}$. The capability of Lf to bind to cell membrane receptors, viral particles, or both may contribute to its 
capacity to hinder viral entry. According to recent research, viral entry is a difficult process involving cell surface components, virus attachment, and adhesion to a more significant attractive cellular receptor to begin cell penetration. Lf limits viral entrance and suppresses virus growth after it reaches the cell in the case of HIV. Lf may thus have an indirect antiviral impact on immunological cells, which are essential during the initial phases of viral infection ${ }^{25}$. Lf and ovotransferrin act directly against viruses and bacteria that may cause secondary infections in COVID19 patients, thus protecting them against infections that might occur. These antimicrobials early on, when noncritical conditions appear, can help prevent them from becoming complicated ${ }^{\mathbf{2 6}}$. They can also be used as a preventive for those who are more susceptible to infection, with smaller doses being given, reducing the chance of infection. Oral consumption of Lf is the most effective method since the number of SARSCoV-2 conditions is increasing ${ }^{27}$. Lf and ovotransferrin, in particular, exhibit systemic effects after ingestion. Lf-containing milk or Lf-supplemented yogurt helps treat viral infections in studies ${ }^{28}$. The main objective of the present review is to summarize the pharmacological activities and protective role of Lf against SARS-CoV-2 infection with possible molecular mechanisms.

\section{BIOCHEMISTRY OF LACTOFERRIN}

Lf are single-chain polypeptides that include 1-4 glycans and have an average molecular weight of approximately $80,000 \mathrm{Da}$, based on species ${ }^{1}$. Because of Baker and colleagues' groundbreaking research, the 3-D conformations of bLf and hLf have become understood in precise detail ${ }^{\mathbf{2 9}, 30}$. A thorough investigation by Montreuil, Spik, and colleagues clarified the architecture of glycans related to Lf in various species $^{31,32}$. Although the three-dimensional structures of bLf and hLf are similar, they are not identical. According to the C-terminal and $\mathrm{N}$-terminal portions of the molecule, every Lf molecule contains two parallel lobes, the C- and N-lobes, respectively. N1, N2, C1, and $\mathrm{C} 2$ are the designations of all these domains, correspondingly ${ }^{33}$. In bLf, N1 represents the sequences 1-90 and 251-233, N2 represents 91-250, C1 represents 345-431 and 593-676, and C2 represents 432592; the sequence 334-344 represents the so-called hinge, which is a three-turn helix structure that plays a key role in domain opening and closing ${ }^{34}$. The existence of disulfide bonds within cysteine residues contributes to the second configuration. When the amino acids Asp60, Tyr92, Tyr192, and His253 cleave from the protein, they lead to ferric ion binding; in both lobes, (bi)carbonate competes with iron for binding ${ }^{\mathbf{1}}$. The Asn residues at locations 233, 281, 368, 476, and 545 in bLf are five possible locations for N-glycan confirmation. Nevertheless, scientific research demonstrates that only four N-linked glycans, Asn281, seem to be omitted ${ }^{33}$. The amino acid Asn476 appears to be conserved throughout animals. Spik et al. ${ }^{32}$ provided an excellent review of the glycans linked to Lf from several species, demonstrating the diversity of these structures ${ }^{35}$.

\section{Iron binding}

Lf present in breast milk is mostly apo-Lf. Lf has an extremely high affinity for iron and an attraction constant of approximately $10^{20^{36}}$. The ability of Lf to bind iron is based on bicarbonate availability (minute quantities). The interaction site appears to be optimized for binding ferric iron and bicarbonated area, charge, and stereochemistry. It is evident from many conformational studies that using different anions and cations or utilizing genetically changed genes $\mathrm{Lfs}^{37}$. In terms of iron binding, oxalates may substitute for bicarbonates but not citrate. On the other hand, citrate can attach to bLf in separation, which is consistent with the in vivo scenario in milk. High amounts of citrate may reduce Lf's ability to bind iron, relying on bicarbonate levels ${ }^{38}$. Other cations, such as copper, could be bonded in the aperture and alter the intake of the optimum wavelength. For example, ferric iron-saturated Lf absorbs best at $466 \mathrm{~nm}$, while copper $\left(\mathrm{Cu}^{2+}\right)$-saturated Lf absorbs best at $434 \mathrm{~nm}$. $\mathrm{Mn}^{3+}, \mathrm{Co}^{3+}$, and $\mathrm{Zn}^{2+}$, in addition to $\mathrm{Cu}^{2+}$, might be connected ${ }^{39}$.

Ward et al. ${ }^{40}$ recovered C- and N-lobe hLfs from Aspergillus awamori. It had been changed for alanine, whether in the C-lobe or the N-lobe, and two tyrosine residues important in iron-binding, using sitedriven mutagenesis. According to their results, the Clobe has a more prominent role in iron stability than the N-lobe. The iron-binding domains of both Lfs' $\mathrm{N}$-lobes were examined ${ }^{\mathbf{4 1 , 4 2}}$. Using $\mathrm{pH}$-induced iron discharge studies, they discovered that the absence of the Asp60 residue in domain N2 did not affect iron retention. They also found evidence of iron stabilizing connections between the N-lobe $(30 \mathrm{kDa}$ tryptic fragment) and the C-lobe (a $50 \mathrm{kDa}$ tryptic fragment) ${ }^{\mathbf{4 3}}$. When the $\mathrm{pH}$ fell under 4, bLf began to discharge iron, while hLf was more resilient to discharge when the $\mathrm{pH}$ fell under $3^{\mathbf{4 4}}$. Furthermore, they demonstrated that complete deglycosylation of both tryptic N-lobe segments resulted in a $50-100 \%$ decrease in ironbinding ability. Nevertheless, no reduction in ironbinding was observed in experiments using adherent deglycosylated recombinant hLf ${ }^{35}$. 


\section{Strong cationic N-terminus}

Both hLf and bLf include significant cationic peptide sequences at the $\mathrm{N}$-terminus, contributing to various essential interacting properties. The interaction of bacterial LPS with human and bLf is mediated by a loop in the $\mathrm{N} 1$ region with a high attraction binding area; the C-lobe appears to have weak attraction binding regions (100 - 130 times lower affinity) ${ }^{4}$. The human loop is composed of 28-34 amino acids, whereas the bovine loop consists of 17-41 amino acids. Preeti et al., ${ }^{45}$ and Van Berkel et al., ${ }^{46}$ investigated the interaction of hLf with heparin, lysozyme, LPS, and deoxyribonucleic acid (DNA) using intact and Nterminally removed Lf. They showed that iron saturation did not affect the four-compound interaction. The removal of one or more arginine residues $\left(\mathrm{Arg}^{2}, \mathrm{Arg}^{3}, \mathrm{Arg}^{4}\right.$, and $\left.\mathrm{Arg}^{5}\right)$ reduced Lf interaction to various degrees, with the deletion of more arginine residues having the most significant impact. Having recombinant Lf lacking the first five amino acid residues $\left(\mathrm{Gly}^{1}-\mathrm{Arg}^{2}-\mathrm{Arg}^{3}-\mathrm{Arg}^{4}-\mathrm{Arg}^{5}\right)$, there was no interaction ${ }^{45}$. This shows how vital this length of four arginine residues in biomolecule association is for host defense.

According to Legrand et al. ${ }^{41}$, the number of binding domains of hLf for human lymphoblast $\mathrm{T}$ cells was most remarkable for the whole molecule. Nevertheless, it gradually decreased from approximately 100 000 per cell to 17000 per cell when $\mathrm{Arg}^{2}, \mathrm{Arg}^{3}$, and $\mathrm{Arg}^{4}$ were removed ${ }^{47}$. The binding characteristics of intact hLf and bLf were quite similar. According to scientists, the interaction takes place on the cell's sulfated molecules, and the $\mathrm{Arg}^{5}$ residue has no function. Due to its known antibacterial action, the cationic Nterminus of bLf is of particular interest ${ }^{35}$.

\section{THE PHARMACOLOGICAL EFFECT OF LACTOFERRIN}

It has antimicrobial, antiviral, and immunomodulatory properties, which affect both the developing and immature immune systems. Lf is orally injected and has previously been associated with iron deficiency but is now related to direct association with bacterial cell walls ${ }^{48}$. It is important to mention that peptides produced from minimal Lf proteolysis that may be produced upon Lf intake have been shown to contain most of the Lf protective properties, occasionally to a higher degree ${ }^{49}$.

\section{Antibacterial Activity}

Lf bacteriostatic action is due to its ability to attach free iron, one of the components required for bacterial development ${ }^{36}$. Iron-dependent bacteria such as E. coli cannot grow if they do not have enough iron $^{50}$. On the other hand, Lf may act as an iron supplier, boosting the growth of bacteria with fewer iron needs, such as Lactobacillus sp. or Bifidobacterium sp., which are generally regarded as beneficial bacteria $\mathbf{5 1}$. However, certain bacteria can adjust to the changing circumstances and produce siderophores (bacterialderived iron-chelating chemicals) that strive with Lf for $\mathrm{Fe}^{3+}$ ions ${ }^{52}$. Several bacteria, such as those in the Neisseriaceae family, are adaptive to changing circumstances by producing particular receptors that attach Lf and induce variations in the Lf molecule tertiary shape, resulting in iron dispersion ${ }^{53}$.

Lf has also been shown to have bactericidal action (Figure 1). This bactericidal action is not iron dependent, and many mechanisms could induce it. On the membrane of certain bacteria, receptors for the Lf $\mathrm{N}$-domain have been identified. Lf interacting with these receptors causes Gram-negative bacteria to die by disrupting their cell walls, resulting in cell death ${ }^{\mathbf{5 4}}$. The subsequent removal of LPS reduces permeability and increases susceptibility to lysozyme and various antimicrobials. Even if Lf does not contact the cell surface, LPS may eliminate it. Electrostatic interactions between the negatively charged lipid layer and the positively charged Lf layer produce bactericidal activity against gram-positive bacteria ${ }^{55}$. These interactions make a substantial difference in membrane permeability. Lactoferricin, a cationic peptide formed when Lf is digested by pepsin, shows bactericidal activity.

Due to the merging of secondary granules and phagosomes, Lf acts as a source of iron for the catalysis of available radical generation. It increases neutrophil intracellular bactericidal action. Lf inhibits the development of Pseudomonas aeruginosa biofilms in vitro ${ }^{56}$. Bacteria are forced to migrate due to a shortage of iron in their surroundings. As a result, they are unable to attach to surfaces. Lf may play a role in preventing pathogen adherence to recipient cells by adhering to both target cell surface glycosaminoglycan and bacterial invasions ${ }^{57}$. This capacity was initially documented against enteroinvasive E. coli $H B$ 101 and then against Yersinia enterocolica, Yersinia pseudotuberculosis, Listeria monocytogenes, Streptococcus pyogenes, and Staphylococcus aureus ${ }^{58}$. Lf proteolytic action is thought to limit the development of certain bacteria, including Shigella flexneri and enteropathogenic E. coli, by destroying proteins required for colonization. Serine protease inhibitors, on the other hand, may prevent this ${ }^{59}$. 


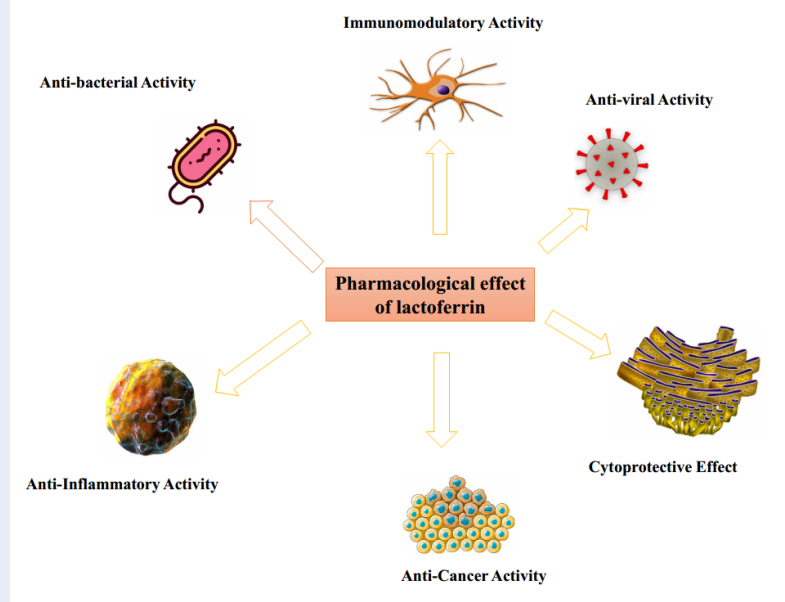

Figure 1: Summarize the pharmacological/biological activities of lactoferrin.

\section{Immunomodulatory Activity}

The usage of bLf and hLf in the immune system has been investigated in several types of research. Despite contradictory findings, Lf appears to have dual immunomodulatory and immunostimulatory properties (Figure 1). The capacity of Lf to attach endotoxin is thought to play a significant role in immunomodulation ${ }^{53}$. Gram-negative bacteria are subjected to different innate immune system proteins when they infect a human host. TLR-4 recognizes this "pathogenassociated molecular pattern". It triggers a range of immunological reactions in different leukocytes and platelets ${ }^{11}$. Immune system activation is decreased by attaching bacterially produced endotoxin to Lf. This mechanism may avoid overstimulation, which can occur during a condition such as sepsis. According to current research, the hLf 1-11 peptide produced from human lactoferricin may block myeloperoxidase. It is a key host-defense enzyme present in different leukocytes, potentially lowering innate immune activity ${ }^{\mathbf{6 0}}$. In contrast, hLf has been demonstrated to promote the differentiation of dendritic cells and the recruitment of different leukocytes. As a result, the protein acts as an innate and adaptive immune system activator $^{61}$.

Lf, which is found in neutrophil secondary granules, is crucial for host protection. Neutrophils may react to harmful bacteria in many formats. Neutrophils may degranulate at the infected area, releasing the host defense protein mixture in secondary and various secretory granules. These factors may combine to produce a significant localized reaction to bacterial attack $^{61}$. Neutrophils swallow invading microorganisms during the phagocytosis phase once a microbe is caught within the neutrophil. The phagocytic vacuole merges with the granules, and the bacteria are natively destroyed. The formation of neutrophil extracellular traps (NETs), which are used in the third stage, is caused by DNA escaping from neutrophil nuclei ${ }^{24}$. In a "kamikaze-like" process, intracellular granules mix with the nucleus, while host defense proteins, such as DNA and nuclear proteins, are all released into the extracellular space ${ }^{62}$. Bacteria are subsequently captured in NETs, where host defense proteins may attack them. Lf may attach to DNA, and because of its strongly positively charged $\mathrm{N}$-domain, it will stay linked with ejected DNA in the NETs, in which it can continue to aid in bacterial death. Because several proteolytic enzymes are expelled from the granules, lactoferricin or specific peptides may also be excreted locally from the adhering Lf protein. However, this possibility has not yet been explored ${ }^{63}$.

\section{Anticancer Activity}

The anticancer potential of Lf has been linked to the stimulation of NK cells in a similar study. However, there is a negative correlation between endogenous hLf production and the prevalence of cancer in some cancer cell lines, which is associated with a substantial reduction in hLf messenger ribonucleic acid (mRNA). Lf gene silencing has been related to some molecular events in cancer cells, including regulator and gene hypermethylation, along with actual gene sequence alterations. Zhang et al. ${ }^{13}$ showed that restoring hLf gene transcription with a methyltransferase blocker reduced cancer cell growth and metastasis in an oral squamous cell carcinoma system. Both hLf and bLf were proven to have anticancer action in protecting and treating tumors. Lf therapy was shown to be effective in suppressing development, metastasis, and tumor-related angiogenesis and in enhanc- 
ing chemotherapy in many experimental animals harboring various kinds of cancers, notably lung, tongue, esophageal, liver, and colorectal cancer.

Although Lf use in clinical studies for tumor protection in humans is nearly impossible for most cancers, studies on its possible usages during the cure of certain precancerous lesions to avoid their transition into potentially tumorigenic cells have been conducted. The Tsuda research team investigated the inhibitory action of orally administered bLf on the formation of precancerous adenomatous colorectal polyps in a clinical trial performed at the $\mathrm{Na}$ tional Cancer Center Hospital in Tokyo, Japan, between 2002 and 2006. Individuals were randomly allocated to receive 0 (placebo), 1.5 , or $3 \mathrm{~g}$ of bLf each day for a year ${ }^{64}$. The findings revealed that the smaller dosage had no impact. The more potent dose was effective in slowing the development of colorectal polyps in individuals aged 63 or younger relative to the placebo group. Surprisingly, serum hLf concentrations in patients receiving $3 \mathrm{~g}$ of bLf were found to be significantly higher after 3 months of therapy, indicating an increase in neutrophil activity ${ }^{\mathbf{6 4}}$ . The research was enhanced in 2014 when a similar group presented data on the relationship between immunological characteristics and polyp size ${ }^{65}$. Enhanced NK-cell action and greater concentrations of the cluster of differentiation $4^{+}\left(\mathrm{CD}^{+}\right)$cells in the growth were sustained with adaptive immunity stimulation. It also reduced the concentrations of polymorphonuclear neutrophils, and growing levels of S100A $8^{+}$cells in the polyps, sustained with downregulation of inflammatory stimuli, were seen in study subjects with regressing cysts. Consequently, even though the molecular processes are still unknown, the Tokyo clinical study is a significant step forward in demonstrating the efficacy of oral bLf treatment in preventing cancer in people ${ }^{66}$.

Aside from broad clinical implications, many molecular pathways underpinning Lf anticancer activity have been discovered, such as cell cycle regulation, apoptosis promotion, migration and invasiveness inhibition, and immunomodulation ${ }^{67}$. Except for the indirect immunomodulatory mechanism, the other processes necessitate Lf's direct identification and choice of tumorous and normal cells, involving a central association with unique tumor cell surface receptors or a secondary interaction through differential intracellular network regulation ${ }^{68}$. Few examples of initial identification between Lf and tumor cell surface receptors have been documented thus far. In this regard, tumor cells usually have significant levels of proteoglycans, glycosaminoglycans (GAGs), and sialic acids, all of which are recognized Lfs interactors ${ }^{69}$. Lf anticancer specificity and sensitivity may be based on this poor detection. The N-terminal region of hLf, which includes a unique sequence of four consecutive arginine residues $\left(G^{1} R R R R^{5}\right)$, was required for hLf interaction with GAGs on the human colon carcinoma cell line HT29-18-C1 as well as Jurkat human lymphoblastic $\mathrm{T}$ cells ${ }^{70}$. Surprisingly, the Nterminal portion of bLf, which has a unique consensus sequence $\left(\mathrm{A}^{1} \mathrm{PRKN}^{5}\right)$ compared to hLf, may bind with cell membrane-linked GAGs.

Furthermore, Riedl et al. ${ }^{71}$ discovered that phosphatidylserine, a cytoplasmic-membrane constituent abundant in tumor cells, is a critical focus for the unique anticancer action of human lactoferricin derivatives. This main selective association through cell surface receptors may explain the most ancient role attributed to Lf, namely, its lethal effect. Similarly, large dosages of both hLf and bLf, as well as their generated peptides, have been demonstrated to cause cytotoxicity and cell death in both prokaryotic and eukaryotic pathogens, as well as tumor cells. Lf cationic charge, which may enhance electrostatic associations with negatively charged cell surface receptors, has been linked to this function ${ }^{72}$. The reduced particular mass weight of Lf-generated cationic peptides may readily penetrate and disrupt cell membranes, causing lysis ${ }^{73}$. In addition, antimicrobial peptides are used in several recent cancer therapies because they have excellent selectivity for cancer cells and minimal toxicity for normal cells. Because of their similar cell selectivity, hLf, bLf, and their associated peptides have been studied and proven to play an essential role in cancer prevention and therapy ${ }^{\mathbf{6 6}}$, as shown in Figure 1.

\section{Antiviral Activity}

Lf was only shown to effectively prevent viral infection in several instances (Table 1). In contrast, many viruses are susceptible to Lf inhibitory effects. This group includes various enveloped viruses, such as HSV 1 and 2, human cytomegalovirus, HIV, hepatitis $B$, hepatitis C, RSV, hantavirus, and four naked viruses (rotavirus, poliovirus, adenovirus, and enterovirus 71) ${ }^{74}$ that Lf has been shown to diminish suppress (Table 1 ). This inhibitory action is shown in both hLf and bLf. This is mediated not only by adherent Lf but also by enzymatic fragments of the molecule, as seen in HSV, cytomegalovirus, adenovirus, and rotavirus ${ }^{75}$. The impact on viral illness does not seem to be linked to removing iron from the surroundings. It has been seen in various instances, 


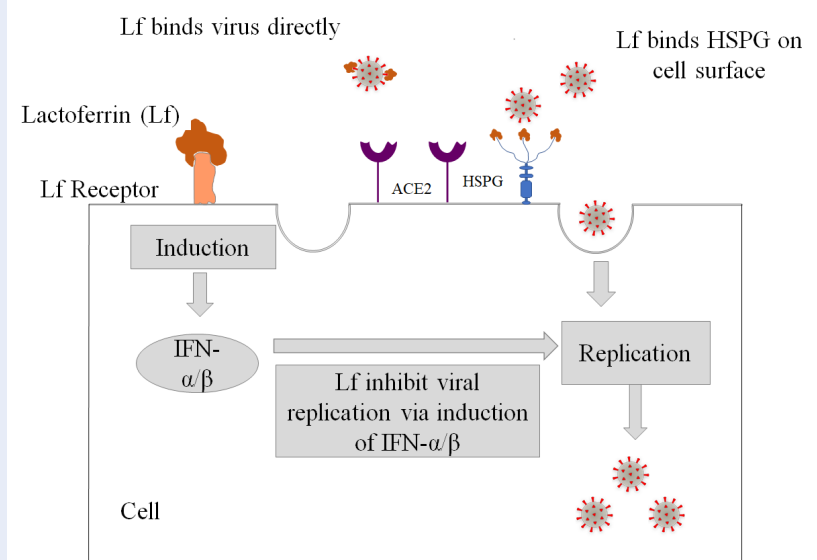

Figure 2: Lactoferrin (Lf) has three potential antiviral mechanisms: (i) direct virus binding; (ii) Lf binding heparan sulfate proteoglycans (HSPGs) on the host cell surface, reducing viralsurfing and subsequent viral entry; and (iii) Lf inhibition of viral replication via induction of intracellular cell signals. IFN stands for interferon, and ACE2 stands for angiotensin-converting enzyme 2.

often with metal-saturated Lf isoforms. However, the explanation for this is unclear. Regarding the mode of action of Lf on viruses, it is widely recognized that the inhibitory effect occurs during the initial stages of viral penetration instead of blocking virus multiplication after infection of the host cell ${ }^{\mathbf{6 0}}$, as shown in Figure 2. Lf binds directly to several sensitive viruses. Antiviral activity can also be achieved by linking to target cell molecules, which the virus uses as a receptor or coreceptor ${ }^{76}$.

Lf antiviral action has also been shown in a limited in vivo study. Lu et al. ${ }^{77}$ reported the initial discovery, observing that Lf increased survival chances in mice treated with the Friend virus complex. Before viral introduction, Fujihara and Hayashi ${ }^{78}$ found that superficially applied bLf inhibited HSV-1 development in the murine cornea. Shimizu et al. ${ }^{79}$ discovered that iron-saturated bLf protects mice from cytomegalovirus infection. Ultimately, Tanaka et al. ${ }^{\mathbf{8 0}}$ showed that bLf reduces HCV viremia in chronic hepatitis $\mathrm{C}$ patients. A finding was later confirmed by Iwasa et al. ${ }^{81}$ in patients with high viral loads and HCV genotype 1b. Apart from its direct impact on viral components or host cells, Lf has been shown in vivo to have an indirect impact via its effect on immune cells, as shown in vivo toward the Friend virus complex and murine cytomegalovirus. The ability of Lf to attach precisely to many virus particles or viral receptors has indicated that this protein might be used to selectively distribute antiviral medicines ${ }^{82}$, as shown in Figure 2.

Moreover, due to its reported impact on SARS-CoV internalization and its capacity to reduce the inflammatory reaction, Lf may have a preventative role in SARS-CoV-2 infection. Lf has been shown in certain trials to prevent pathogenesis by the pseudovirus
SARS $^{83}$. In this regard, it is thought that breast milk, which consists of a substantial portion of Lf, can provide considerable prevention to newborns toward the new coronavirus SARS-CoV-2. On the other hand, additional research is needed to understand the novel coronavirus behavior and treatments. However, Lf appears to be an up-and-coming preventive option ${ }^{15}$. Its antiviral effects are derived from blocking receptors such as heparan sulfate glycosaminoglycan cell receptors. Its interaction with viral hemagglutinin (HA) allows Lf to penetrate the viral coating. The glycosylation characteristic of the molecule may provide an important understanding of these interactions. Certain studies have shown that changing the glycosylation of the molecule can change the signaling strength of different TLRs participating in viral particle identification, such as TLR-3 and TLR- ${ }^{24}$. Despite its great tolerability, the results of LF as an oral supplement remain irregular, both in terms of prevention and treatment of viral infections. Oral supplementation with LF is well tolerated. However, the results of viral infection prevention and treatment remain mixed. Because of the wide range of recruiting and treatment methods used, as well as the poor research quality, the results are likely to be heterogeneous. SARS-CoV-2 and other viruses will need to be studied in more detail in studies with better designs ${ }^{84}$. 
Table 1: The antiviral activities of $L f$ for some viruses

\begin{tabular}{|c|c|c|c|c|c|}
\hline Type of virus & Enveloped/nake & DNA/RNA & Sources of LF & Mechanism & References \\
\hline Influenza A & Enveloped & RNA & Bovine & $\begin{array}{l}\text { Interfering with viral } \\
\text { hemagglutinin fusogenic } \\
\text { activity }\end{array}$ & 85 \\
\hline RSV & Enveloped & RNA & Human & $\begin{array}{lr}\text { Modulating } & \text { RSV- } \\
\text { induced IL8 } & \text { expression } \\
\text { and RSV F protein } \\
\text { attachment }\end{array}$ & 86 \\
\hline adenovirus & Naked & DNA & Bovine & $\begin{array}{l}\text { Competing with viral } \\
\text { particles for cell mem- } \\
\text { brane HS incorporated } \\
\text { in target cell mem- } \\
\text { branes by binding to the } \\
\text { adenovirus penton base. }\end{array}$ & 87 \\
\hline SARS-CoV & Enveloped & RNA & Human & $\begin{array}{l}\text { Promoting natural killer } \\
\text { cell activity and neu- } \\
\text { trophil aggregation and } \\
\text { adhesion by attaching } \\
\text { to heparan sulfate gly- } \\
\text { cosaminoglycan (HSPG) } \\
\text { and inhibiting the initial } \\
\text { interaction between } \\
\text { SARS-CoV and host cells }\end{array}$ & 88 \\
\hline $\begin{array}{l}\text { Enterovirus } \\
71\end{array}$ & Naked & RNA & Bovine & $\begin{array}{l}\text { Binding to viral protein } 1 \\
\text { protein and host cells }\end{array}$ & 89 \\
\hline Cytomegaloviru & Enveloped & DNA & Human & $\begin{array}{l}\text { Lf prevents CMV cell in- } \\
\text { vasion and has indirect } \\
\text { antiviral effects on CMV } \\
\text { infections by stimulating } \\
\text { the immune system }\end{array}$ & 90 \\
\hline HSV-1 & Enveloped & DNA & Bovine & $\begin{array}{l}\text { By competing with HSV } \\
1 \text { for the heparan sulfate } \\
\text { receptor on the cell sur- } \\
\text { face and inhibiting VP } 16 \\
\text { from being translocated } \\
\text { to the nucleus, it affects a } \\
\text { postentry step of viral in- } \\
\text { fection }\end{array}$ & 91 \\
\hline
\end{tabular}

Abbreviations : RSV: respiratory syncytial virus; IL: interleukin; HS: heparan sulfate; SARS-CoV: severe acute respiratory syndrome coronavirus; HSPG: heparan sulfate proteoglycans; CMV: cytomegalovirus. 


\section{Cytoprotective Effect}

Protein chaperones are made from the ER, which is a protein-folding machinery. The ER is responsible for protein folding and detects misfolded or unwrapped proteins. Pathological analyses suggest that ER stress is a frequent source of a variety of illnesses, particularly when the stress is solid or persistent enough to induce cell death or damage. Whenever ER stress is constant and the ER folding limit is exceeded, cellular malfunction and cell mortality are common outcomes $^{92}$. Disruption of typical ER activities triggers an evolutionarily conserved cell stress reaction called the unfolded protein reaction. It is designed to accommodate damage but may eventually induce cell mortality if the ER is severely or chronically dysfunctional $^{93}$.

In that study, leptin-deficient (ob/ob) mice were used as animal models of nonalcoholic fatty liver disease (NAFLD). Lf protects Ob/ob mouse liver tissues from oxidative and ER stress. Due to the involvement of hepcidin-induced obesity and hepatic lipid deposition, ER stress has recently been recognized as a cause of iron homeostasis control ${ }^{\mathbf{9 4}}$. Recombinant hLf is given intraperitoneally to relieve or postpone the pathological development of NAFLD to assess Lf hepatoprotective properties ${ }^{18}$. The activation of extracellular signal-regulated protein kinase 1/2 (ERK1/2 and eIF2), as well as NF- $\kappa$ B stimulation and oxidative stress, was shown to be reduced in the liver tissues of LF-treated ob/ob mice compared to vehicletreated ob/ob mice ${ }^{95}$. Consequently, it is suggested that the cytoprotective function of Lf is linked to the inhibition of ER stress. The hepatic p-eIF2 and p-NF$\kappa \mathrm{B}$ expression rates were significantly greater in ob/ob animals than in Lf-treated ob/ob mice. This suggests that Lf treatment may reduce ER stress induced by hepatosteatosis ${ }^{\mathbf{9 6}}$. It has been demonstrated that Lf prevents ER stress and the development of autophagy in injured hepatocytes due to its cytoprotective effect. It also induces upregulation of HIF-l $\alpha /$ VEGF to aid hepatic activity retrieval ${ }^{97}$.

A recent study showed that Lf had a cytoprotective impact on the survival of HUVECs that had been subjected to $\mathrm{H}_{2} \mathrm{O}_{2}$-induced oxidative damage using the MTT assay ${ }^{98}$. HUVECs were pretreated with Lf at 25-100 $\mu \mathrm{g} / \mathrm{ml}$ doses, which decreased cell mortality caused by $\mathrm{H}_{2} \mathrm{O}_{2}$ in a concentration-dependent manner. The survival of HUVECs $(\mathrm{P}<0.001)$ was significantly reduced after 2 hours of treatment with $0.5 \mathrm{mM}$ $\mathrm{H} 2 \mathrm{O} 2$. No cytoprotective activity was detected at 6.25 and $12.5 \mu \mathrm{g} / \mathrm{ml} \mathrm{Lf}^{\mathbf{9 8}}$.

\section{Anti-Inflammatory Effect}

Along with directly inhibiting bacterial growth, research indicates that Lf may reduce the inflammation caused by microbial exposure. Animal studies have shown that Lf therapy protects against Helicobacter pylori-induced gastritis, LPS-induced gut mucosal viability, endotoxemia, and mortality caused by systemic E. coli or LPS exposure ${ }^{23}$. In vitro and in vivo studies in mononuclear cells and mice show that Lf can reduce inflammation by decreasing the production of a variety of proinflammatory cytokines, such as TNF- $\alpha$, IL- $1 \beta$, and IL- $6^{99}$. This effect could be accomplished primarily by the capacity of Lf to bind molecules that link with the TLR signaling pathway, which is critical for the subsequent host inflammatory process to microbial invasion. Lf has demonstrated that LPS, soluble CD14, and unmethylated cytosines followed by guanine residues $(\mathrm{CpG})$ bacterial DNA are binding and attenuating directly via an immunestimulating reaction ${ }^{43}$. Finally, in vitro studies in monocytic cells suggest that the anti-inflammatory effect of Lf in response to LPS exposure may be related to reduced proinflammatory cytokine synthesis. It follows Lf translocation to the nucleus, which suppresses NF- $\kappa$ B activation ${ }^{100}$.

The opposing-inflammatory impact of Lf is rapidly being recognized as extending beyond reducing microbial-induced inflammation ${ }^{101}$. Inflammatory diseases such as neurodegenerative illness, inflammatory bowel disorder, dermatitis, pulmonary diseases, and arthritis have been shown to stimulate Lf. Furthermore, Lf treatment has been demonstrated in most animal experiments to reduce experimental inflammation in such organs ${ }^{102}$. For instance, Lf prevents chemical and IL-1 $\beta$-driven cutaneous inflammation in humans and animals, chemically induced inflammatory bowel disease in rats and mice, nonsteroidal anti-inflammatory drugs (NSAIDs)-induced colon damage in rodents, and inflammation in a rat model of rheumatoid arthritis ${ }^{103}$. This resistance was linked to a reduction in proinflammatory cytokines, such as TNF- $\alpha$ and IL- $1 \beta$, and/or an enhancement in anti-inflammatory cytokines, like IL-10, in several instances ${ }^{104}$. The potential of Lf to engage with particular receptors on a wide range of immune cells, such as neutrophils, monocytes, macrophages, and lymphocytes, as well as epithelial cells. It indicates that Lf anti-inflammatory action could be responsible for the observed influence on modifying cytokine secretion by these cells primarily through receptor-mediated signaling mechanisms ${ }^{105}$. In a sheep model of allergic asthma caused by tryptase imbalances, several 
additional mechanisms by which Lf may inhibit the inflammatory reaction have been proposed, including the prevention of iron-catalyzed complimentary radical deterioration at areas of inflammation and the elimination of later stages airway blockage and hyperresponsiveness ${ }^{60}$. Campione, E., et al. ${ }^{\mathbf{6}}$ revealed that Lf as a protective natural barrier of respiratory and intestinal mucosa against coronavirus infection and inflammation.

\section{ANTIVIRAL ACTIVITY OF LACTOFERRIN AGAINST SARS-COV-2}

Lf has been shown to have extensive antiviral action against a variety of human and animal viruses, including DNA and RNA viruses ${ }^{25,106}$. In the 1980s, mice inoculated with the friend virus complex polycythemia-inducing form were shown to have antiviral activity ${ }^{77}$. Lf is particularly relevant to the present study to eliminate pseudotyped SARS-CoV at a $50 \%$ inhibitory concentration (IC 50) of $0.7 \mathrm{M}$ (Lang et al., 2011). The most common reason for developing COVID-19, in this case, is SARS-CoV-2 ${ }^{24}$.

The capability of Lf to prevent viral entrance might be due to its capacity to attach to cell membrane receptors, viral particles, or both. According to new findings, viral entrance is a complicated procedure requiring cell surface molecules ${ }^{107}$. To initiate cell penetration, these chemicals are first attached to the virus and then to a greater affinity for cellular receptors ${ }^{108}$. Lf can also attach straight viral particles, such as HCV, to redirect them away from specific sites ${ }^{109}$. In HIV, Lf inhibits virus proliferation once it reaches the cell, in addition to limiting viral entrance ${ }^{\mathbf{1 1 0}}$. Subsequently, Lf can have an indirect antiviral impact on immunological cells, which are important in the initial phases of viral infection.

\section{Two-stage correlation with host cell recep- tors}

The virus must first adhere to it and later perforate the cellular membrane to enter the host cell. Near the Nterminus of Lf, a strongly alkaline area may be coupled with several negatively charged macromolecules ${ }^{25}$. This is a key component of Lf antiviral action since many macromolecules, such as GAGs, often serve as receptors on host membranes, which enable viruses to interact with them ${ }^{111,112}$. Heparan sulfate proteoglycans (HSPGs) have been shown to suppress viruses such as human RSV, Venezuelan equine encephalitis virus ${ }^{113}$, Echovirus ${ }^{114}$, HSV, dengue ${ }^{111}$, and others ${ }^{115}$
COVID-19 caused by SARS-CoV-2. SARS-CoV-2 is similar to SARS, as it is a positive-strand RNA virus with spikes, envelopes, membranes, and nucleocapsid proteins. It is dangerous to public health because of its high infectivity, death rates, and low recovery percentages ${ }^{116}$. SARS-CoV binds to host cells via $\mathrm{HSPGs}^{117}$, which Lf also uses to adhere to target tissues ${ }^{118}$. Lf has been demonstrated to protect the host against various viral infections by preventing viruses such as HSV from internalizing and filling their attachment sites ${ }^{119}$. The consequences of $\mathrm{Lf}$ on 293E/angiotensin-converting enzyme 2 (ACE2)Myc cells infected with SARS-CoV pseudovirus have been studied ${ }^{88}$. HSPGs (attachment points that allow SARS-CoV to enter the cell) are scattered across the target cell membrane. Lf binds to such attachment sites to inhibit SARS-CoV internalization and disease in infected cells during the initial phase. As a result, Lf may be a promising therapeutic approach for shielding target cells against SARS-CoV pathogeneses.

SARS-CoV and SARS-CoV-2 share $80 \%$ of their genomes and have comparable receptor-binding domain (RBD) configurations, and ACE2 and the RBD 1 helix form a polar bond with the ACE2 peptidase domain (PD) ${ }^{120}$. The main receptor of SARS-CoV-2 has been identified as ACE2, but another disputed independent receptor of SARS-CoV-2 is dendritic cellspecific intercellular adhesion molecule 3-grabbing nonintegrin (DC-SIGN) ${ }^{121}$. DC-SIGN might play a role in ACE2-mediated illness ${ }^{\mathbf{1 2 2}}$. However, no research has shown that Lf can protect host cells via its association with ACE2. By attaching to cell membrane sites such as DC-SIGN, heparan sulfate, and low-density lipoprotein receptors, Lf has been shown to defend host cells from dengue virus invasion ${ }^{123}$. As a result, Lf may block ACE2-mediated illness by interacting with DC-SIGN.

Furthermore, ACE2 is widely expressed in gastrointestinal epithelial cells ${ }^{124,125}$. As a result, SARS-CoV2 internalization in host cells may be detected in the gastrointestinal system, potentially leading to effective disease and replication ${ }^{\mathbf{1 2 6}}$. After oral treatment, Lf stays on the gastrointestinal tract lining, protecting host cells from SARS-CoV-2 ${ }^{1}$.

\section{Fusion with the viral envelope}

The virus attacks host cells by fusing its envelope to the target cell membrane, an important stage in viral illness. It has been shown that Lf attaches to substances on the virus envelope that mediate the infection procedures and prevent fusion, thus trying to prevent infection ${ }^{127,128}$. Various viruses have various 
binding locations. The hemagglutinin type 1 and neuraminidase type 1 (H1N1) virus binding site is $\mathrm{HA}$, and fusion of Lf with HA has been shown to suppress illness ${ }^{85}$. The virus coat glycoprotein HA is a crucial component in viral pathogenicity. When Lf binds to $\mathrm{HA}$, it prevents the virus glycoprotein and host cell receptors from merging and causing infection.

Furthermore, they fuse with the F protein on the viral envelope ${ }^{77}$. RSV, which has been related to severe respiratory diseases in babies, including otitis media and lower respiratory tract involvement (LRTI), is suppressed by $\mathrm{Lf}^{129}$. Lf attaches to the F1 component of the F protein, stopping RSV from entering epithelial cells, limiting the inflammatory reaction induced by RSV, and reducing Hep-2 cell infection. Lf protects the host cell from adenovirus invasion by adhering to the penton base of the virus ${ }^{\mathbf{1 3 0}}$. Overall, the ability of Lf to defend against viral diseases is noteworthy. However, it is important to examine whether Lf is similarly efficient in SARS-CoV-2 and discover the attachment sites on SARS-CoV-2. Lf has shown significant, wide-ranging antiviral potency, showing that it might be used to prevent and treat SARS-CoV$2^{14,131}$. SARS-Co-V may be inhibited by invading host cells by Lf therapy on HSPGs and ACE2 ${ }^{88}$, as illustrated in Figure 2. Lf has a broad spectrum of immunoregulatory and anti-inflammatory characteristics that may benefit SARS-CoV-2 therapy and protect against its catastrophic consequences on various $\operatorname{organs}^{132,133}$.

\section{Blocking viral attachment with host cells}

Lf inhibits viral attachment, surface buildup on the host cell, and virus penetration into the cell by operating on cell targets ${ }^{106,134}$. Its antiviral action originates in the earliest phases of infection on bare and enveloped viruses, inhibiting the virus from penetrating the host cell ${ }^{\mathbf{1 3 2}}$. It inhibits the proliferation of many infections by interfering with the breakdown of the cellular membrane, the sequestration of iron, the prevention of pathogen adherence to host cells, and the creation of biofilms ${ }^{132}$. The initial step of viral infection, notably in COVID-19, is identifying the first cell attachment receptors. Engaging with these cell receptors is found in glycosaminoglycan heparin sulfate $^{\mathbf{8 8}}$. Lf can inhibit viral infections. By adhering to cell-surface HSPGs, they have been demonstrated to function as essential cofactors for SARS-CoV-2

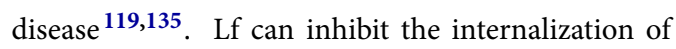
certain viruses, including the SARS pseudovirus ${ }^{119}$. Furthermore, Lf has been demonstrated to prevent the entrance of murine coronavirus and human coronaviruses such as hCoV-NL63 ${ }^{136}$, which are similar to
SARS-CoV-2. Cathepsin L, a lysosomal peptidase essential for endocytosis, is a cell entrance route utilized by SARS-CoV-2 ${ }^{137,138}$ and has similarly been shown to be inhibited explicitly by Lf $^{139}$.

The viral spike protein interacts with the ACE2 receptor and the HSPG attachment factor on the host cell to bind to host cells ${ }^{135}$, as mentioned in Figure 2. Human coronavirus OC43 HCoV-OC43 virus or SARSCoV-2 pseudovirus fragments were used as SARSCoV-2 agents. Cell pretreatment and virus inactivation tests were conducted to determine whether Lf interacts with viral adherence via associations with the target cell or the virus. Early cure of rhabdomyosarcoma (RD) cells, mostly $1000 \mathrm{~g} / \mathrm{ml}$ bLf preceding viral illness, lowered the appearance of internal cell viral protein by approximately $80 \%$ relative to the $\mathrm{H}_{2} \mathrm{O}$ exposure reference specimen. The precipitate viral concentration was lowered by approximately $1 \log 10$ units $^{83}$. SARS-CoV-2 pseudovirus luciferase function was reduced to approximately half that of the $\mathrm{H}_{2} \mathrm{O}$-exposed reference after pretreatment of Vero E6 cells with $1000 \mathrm{~g} / \mathrm{ml}$ bLf. To determine whether Lf directly influences $\mathrm{HCoV}-\mathrm{OC} 43$ viral fragments, researchers pretreated $\mathrm{HCoV}-\mathrm{OC} 43$ viruses with 1000 $\mathrm{g} / \mathrm{ml}$ bLf or the equivalent amount of sterilized $\mathrm{H}_{2} \mathrm{O}$ (placebo) for 3 hours at $37{ }^{\circ} \mathrm{C}$ and then measured the viral titer in rhabdomyosarcoma cells. The virus treated with bLf produced the equivalent quantity of plaques as the $\mathrm{H}_{2} \mathrm{O}$-exposed reference at a $10^{6}$-fold dilution. Since the final concentration in the plaque test was $0.001 \mathrm{~g} / \mathrm{ml}$, much beyond its lowest suppressive level (effective concentration $\left(\mathrm{EC}_{50}\right)=37.92 .5$ $\mathrm{g} / \mathrm{ml}$ ), bLf seemed to have no impact on plaque production. These findings showed that rather than the virus itself, bLf suppresses viral adherence by attaching to target cells ${ }^{83}$.

\section{Lf inhibits SARS-CoV-2 pseudovirus replica- tion in multiple cell lines}

The pseudovirus neutralization test is a well-known paradigm for studying viral penetration in target cells. It has been frequently utilized to evaluate the antiviral efficacy of viral entrance antagonists 140,141 . To determine whether the antiviral activity of Lfs toward SARS-CoV-2 is cell sort-reliant, researchers tested bLf and hLf in SARS-CoV-2 pseudovirus assays in 3 different cell lines: Vero E6 cells, Calu- 3 cells, and 293T cells overexpressing ACE2 (293T-ACE2) ${ }^{83}$. Vero E6 and 293T-ACE2 cells have high levels of ACE2 on the apical membrane but low levels of transmembrane protease serine 2 (TMPRSS2) ${ }^{\mathbf{1 4 2}}$. As a result, SARSCoV-2 enters such cells via endocytosis and activates 
endosomal cathepsin $\mathrm{L}$ to activate viral spike proteins ${ }^{143}$. Calu-3, on the other hand, is a human lung epithelial cell line that expresses both ACE2 and TMPRSS2 ${ }^{144}$.

The SARS-CoV-2 spike protein may be activated by TMPRSS2 on the cell membrane, allowing immediate cell entry at the cell surface. E-64d, a cathepsin L blocker, and camostat mesylate, a TMPRSS2 agonist, were used as controls in the SARS-CoV-2 pseudovirus invasion tests. Both bLf and hLf, with $\mathrm{IC}_{50}$ values ranging from 26.2 to $49.7 \mathrm{~g} / \mathrm{ml}$ and $34.4-163.5 \mathrm{~g} / \mathrm{ml}$, respectively, reduced SARS-CoV-2 pseudovirus entry in all 3 cell lines in a dose-dependent manner. The antiviral test findings from infectious HCoVs show that bLf is more potent than hLf. These findings suggest that Lfs block SARS-CoV-2 pseudovirus entrance regardless of cell type ${ }^{83}$.

\section{Bind to heparin in vitro}

According to previous research, LF inhibits SARS$\mathrm{CoV}$ pseudovirus illness in human embryonic kidney 293 cells (HEK293E)/ACE2-Myc cells by adhering to HSPGs on the surface of the cell ${ }^{\mathbf{8 8}}$. Furthermore, through its association with the membrane (M) protein, HCoV-NL63 has been demonstrated to use HSPGs as an adherence receptor for virus assembly to target ${ }^{136,145}$. SARS-CoV-2 spike protein coreceptors have recently been identified on cell surfaces, facilitating further attachment to the ACE2 receptor ${ }^{135}$. Based on these observations and the data described above, Lf is proposed to achieve its extensive antiviral effect toward coronaviruses by attaching to HSPGs and thereby passively inhibiting the association between the viral spike protein and ACE2 (Figure 2). They used heparin (Sigma Cat. \# H3393) to verify this idea as an HSPG mimic. They used differential scanning fluorimetry (DSF) to detect heparin straight attachment to bLf and hLf ${ }^{146}$. When a ligand binds specifically to a protein, the target protein is generally stabilized, resulting in a higher melting temperature. According to the DSF findings, heparin raised the melting temperature of both bLf and hLf reliant on the amount of the drug, suggesting direct attachment of bLf and hLf to heparin.

Furthermore, bLf has a greater binding affinity for heparin than hLf, as seen by the higher melting temperature, consistent with bLf having more robust antiviral activity than hLF. The associated HCoVOC43 or human coronavirus-NL63 (HCoV-NL63) membrane of Vero E6 cells or RD cells was measured using immunofluorescence labeling and reverse transcription-polymerase chain reaction (RT-PCR) after a viral adherence experiment was performed in the presence of various pairings of heparin and/or Lf. Fluorescent indicators on the membrane of $\mathrm{RD}$ cells exposed to the $\mathrm{H}_{2} \mathrm{O}$ control indicate that the $\mathrm{HCoV}-\mathrm{OC} 43$ virus had bound to the target cell surface $^{83}$. Fluorescence markers on the cell surface were decreased in bLf-exposed specimens in a dosedependent fashion, indicating that bLf prevented viral adherence. The immunofluorescence level showed that heparin administration did not influence viral adhesion. When bLf was pretreated with heparin before being added to the viral attachment test, the fluorescence responses were recovered $(86 \%$ at $30 \mathrm{~g} / \mathrm{ml}$ heparin and $19 \%$ at $10 \mathrm{~g} / \mathrm{ml}$ ), and the suppression of viral adherence was eliminated ${ }^{83}$. Because no particular antibodies against HCoV-NL63 were accessible, the immunofluorescence test for HCoV-NL63 was not conducted. Instead, RT-qPCR was used to determine the number of viruses adhering to the cell surface ${ }^{147}$. The antiviral action of bLf is mediated by either direct binding to SARS-CoV-2 particles or obscuration of the host cell receptors for these pathogen proteins. More evidence points to a direct interaction between bLf and the spike glycoprotein, which is supported by results from molecular docking and simulations of molecular dynamics. According to the simulation, this identification is extremely likely to take place because of the high number of atomistic contacts found and the permanence of these connections over the simulation. bLf may therefore prevent viral entrance into host cells ${ }^{148}$.

\section{Synergistic antiviral effect with remdesivir}

The World Health Organization (WHO) has approved remdesivir as the most potent antiviral for the current COVID-19 outbreak that SARS-CoV-2 causes. Remdesivir is expected to adhere to SARS-RNAdependent CoV-2 RNA polymerase with a binding energy of $-7.6 \mathrm{kcal} / \mathrm{mol}$, potentially inhibiting ${ }^{149}$, and the primary viral protease with a binding energy varying from -6.4 to $-7.2 \mathrm{kcal} / \mathrm{mol}^{150}$.

Combination medication has been widely investigated for the treatment of oncology, parasitic, and viral infections ${ }^{\mathbf{1 5 1 , 1 5 2}}$. It has many benefits over monotherapies, including delayed advancement of drug opposition, synergistic effectiveness, and fewer side effects due to more secondary medication. Using the HCoV-OC43 antiviral cytopathic effect (CPE) test, the combined therapeutic potential of bLf and remdesivir was investigated. Remdesivir is a Food and Drug Administration (FDA) approved antiviral that inhibits SARS-CoV-2 polymerase. As previously 
stated, the combination index versus $\mathrm{EC}_{50}$ data of drugs was shown at various combined rates ${ }^{153}$. The CIs for all combination ratios used in many experiments indicate that bLf had a synergistic antiviral impact with remdesivir in combination treatment.

\section{FUTURE PERSPECTIVE}

Because of the direct antiviral activities of Lf and ovotransferrin against various viruses and their antimicrobial actions against a variety of microorganisms that could induce secondary infections in COVID-19 patients ${ }^{154}$. Their immunomodulatory characteristics enhance antimicrobial reactions while promoting inflammatory resolution, oxidative stress, and excessive inflammatory cytokine manufacturing (particularly IL- 6 and TNF- $\alpha$ ). The primary recommendation is to use these antimicrobials as soon as signs appear to prevent noncritical situations from becoming serious. However, they may also be used to avoid people at higher risk of infection, where lower doses could be given to reduce infection risk. Because the incidence rate of SARS-CoV-2 infection is rapidly increasing, oral delivery is the most efficient approach. This is especially true for $\mathrm{Lf}$ and ovotransferrin, which have systemic effects after ingestion. Pasteurized entire milk has been shown to influence the shifting of phagocytes from M1 to M2. Other than those found in ovotransferrin, many peptides in egg white have shown antioxidant and ACE-inhibitory consequences ${ }^{155,156}$. Individuals who are extremely sick and on ventilators, on the other hand, may require extra caution with the technique. Lf might be used intravenously or through nebulization. In this case, liposomal bLf nebulizer treatment is available. Because of its availability and low cost, this antibiotic is appealing as a treatment alternative (in comparison to some other medicines, such as remdesivir).

Therapy for latent or chronic viral diseases, common in immunocompromised patients, is potentially a viable use of Lf in conjunction with certain chemotherapeutic drugs. Lf has been shown to work in concert with complement ${ }^{157}$ and immunoglobulin ${ }^{158}$. These findings show that Lf is a complicated and multipurpose protein that plays a role in natural immunity. That research into its antimicrobial properties must always be considered in the context of a larger view of host resistance. Lf antibacterial action results from a protracted evolutionary procedure in which a molecule operates in a complicated picture. This impacts cytokine synthesis, immune cell function, and overall inflammatory reaction modulation ${ }^{159}$. To summarize, Lf should be viewed as a major element in mammalian innate immunity and as a polyvalent regulator that achieves its goal by associating with a variety of factors engaged in infectious or inflammatory activities ${ }^{82}$. There is little question that LF supplementation is an interesting area for further investigation however, the findings of this study do not allow for a firm judgment regarding its potential advantages as a support treatment ${ }^{160}$.

\section{CONCLUSION}

The explosive growth of the SARS-CoV-2 epidemic has become a significant worldwide health issue. As a result, effective therapeutic medicines are needed to guard against and cure SARS-CoV-2. Lf has demonstrated strong antiviral efficacy throughout a broad range, indicating that it might be utilized to cure and treat SARS-CoV-2. For instance, Lf therapy of ACE2 and HSPGs can inhibit SARS-CoV from invading target cells. Lf has many immunoregulatory and antiinflammatory properties that may help treat SARSCoV-2 and limit its catastrophic consequences on a variety of different organs. Additionally, Lf has a superior safety profile than other antiviral medications. Consequently, using Lf to cure COVID-19 may be promising and deserves additional research. Lf may also adhere to viral fragments actively, such as HCV, and keep them away from particular sites. In HIV, Lf limits viral entry and suppresses virus growth once it enters the cell. SARS-CoV-2 and SARS-CoV share $80 \%$ of their genomes, RBD structures, and cellular receptors, and the RBD 1 helix attaches to the $\mathrm{PD}$ of ACE2 through polar activity. Although the threedimensional structures of bovine and hLf are similar, they are not identical. The most common Lf found in breast milk is apolipoprotein. The existence of (limited quantities of) bicarbonate affects the capacity of Lf to bind iron.

Substantial cationic peptide sequences at the Nterminus of both hLf and bLf contribute to several important interaction characteristics. The total number of binding domains in hLf was the maximum for human lymphoblast $\mathrm{T}$ cells. The bactericidal properties of Lf have also been discovered. This bactericidal action is not iron reliant and may be triggered in a variety of ways. The ability of Lf to bind endotoxin is considered important in immunomodulation. LPS (also known as endotoxin) is a constituent of the bacterial outer layer. When TLR-4 recognizes this "pathogenassociated molecular pattern," it induces a range of immunological responses in leukocytes and platelets. Lf gene silencing has been related to many molecular events in cancer cells, including regulator and gene hypermethylation, as well as actual gene sequence alterations. Lf binds to several viruses that are particularly sensitive. Antiviral activity can also be achieved 
by linking to target cell molecules, which the virus uses as a receptor or coreceptor. Lf protects $\mathrm{ob} / \mathrm{ob}$ mouse liver tissues against oxidative and ER stress.

\section{ABBREVIATIONS}

ACE2, Angiotensin-Converting Enzyme2; Asn, Asparagine; $\mathrm{CD}^{+}$, Cluster of Differentiation $4^{+}$; COVID-19, Coronavirus Disease-2019; $\mathrm{Cu}^{2+}$, copper; CPE, Cytopathic Effect; CpG, Cytosines followed by Guanine residues; DSF, Differential Scanning Fluorimetry; DNA, deoxyribonucleic acid; $\mathrm{EC}_{50}$, Effective Concentration 50; E. coli, Escherichia coli; ER, Endoplasmic Reticulum; ERK, Extracellular Signal-Regulated Protein Kinase; FDA, Food and Drug Administration; GAGs, Glycosaminoglycans; HA, hemagglutinin; H1N1, Hemagglutinin type 1 and Neuraminidase type 1; HCoV-NL63, Human Coronavirus-NL63; HEK, Human Embryonic Kidney; HIV, Human Immunodeficiency Virus; HSV, Herpes Simplex Virus; HIF-l $\alpha$, HypoxiaInducible Factor-1 alpha; HSPGs, Heparan Sulfate Proteoglycans; HUVECs, Human Umbilical Vein Endothelial Cells; IC 50, Inhibitory Concentration 50; IL, Interleukin; Lf, Lactoferrin; bLf, Bovine Lf; hLf, human Lf; LPS, Lipopolysaccharide; MTT, 3-(4,5-dimethylthiazol-2-yl)-2,5-diphenyl-2Htetrazolium bromide; NAFLD, Non-Alcoholic Fatty Liver Disease; NK, Natural Killer; NSAIDs, NonSteroidal Anti-Inflammatory Drugs; NETs, Neutrophil Extracellular Traps; mRNA, messenger ribonucleic acid; PD, Peptidase Domain; RSV, Respiratory Syncytial Virus; RBD, Receptor-Binding Domain; RT-PCR, Reverse Transcription-Polymerase Chain Reaction; p-eIF2, phosphorylation of the eukaryotic Initiation Factor 2; p-NF- $\kappa \mathrm{B}$, phosphorylation of the Nuclear Factor kappa-light-chainenhancer of activated B cells; SARS, Severe Acute Respiratory Syndrome; SARS-CoV-2, Severe Acute Respiratory Syndrome Coronavirus-2; TLR, Toll-like receptor; TMPRSS2, Transmembrane protease serine 2; TNF- $\alpha$, Tumor Necrosis Factor-alpha; VEGF, Vascular Endothelial Growth Factor; WHO, World Health Organization.

\section{ACKNOWLEDGMENTS}

The authors concede the support of the Cholistan University of Veterinary \& Animal SciencesBahawalpur, Pakistan, during the write-up.

\section{AUTHOR'S CONTRIBUTIONS}

$\mathrm{KN}$ conceived the original idea and designed the outline of the study. SR and FS equally contributed to and wrote the $1^{\text {st }}$ draft of the manuscript. $\mathrm{KN}$ revised the whole manuscript and formatted it accordingly. All authors have read and approved the final manuscript.

\section{FUNDING}

None.

\section{AVAILABILITY OF DATA AND MATERIALS}

Not applicable.

\section{ETHICS APPROVAL AND CONSENT TO PARTICIPATE}

Not applicable.

\section{CONSENT FOR PUBLICATION}

Not applicable.

\section{COMPETING INTERESTS}

The authors declare that they have no competing interests.

\section{REFERENCES}

1. Wang B, Timilsena YP, Blanch E, Adhikari B. Lactoferrin: Structure, function, denaturation and digestion. Critical Reviews in Food Science and Nutrition. 2019;59(4):580-96. Available from: 10.1080/10408398.2017.1381583.

2. Mikulic N, Uyoga MA, Mwasi E, Stoffel NU, Zeder C, Karanja S. Iron absorption is greater from Apo-Lactoferrin and is similar between Holo-Lactoferrin and ferrous sulfate: stable iron isotope studies in Kenyan infants. The Journal of Nutrition. 2020;150(12):3200-7. Available from: 10.1093/jn/nxaa226.

3. Majka G, Pilarczyk-Zurek M, Baranowska A, Skowron B, Strus M. Lactoferrin Metal Saturation-Which Form Is the Best for Neonatal Nutrition? Nutrients. 2020;12(11):3340. Available from: $10.3390 /$ nu12113340.

4. Fais R, Luca MD, Rizzato C, Morici P, Bottai D, Tavanti A. The $\mathrm{N}$-terminus of human lactoferrin displays anti-biofilm activity on Candida parapsilosis in lumen catheters. Frontiers in Microbiology. 2017;8:2218. Available from: 10.3389/fmicb. 2017.02218.

5. Kumar BG, Mattad S. Comprehensive analysis of lactoferrin $\mathrm{N}$-glycans with site-specificity from bovine colostrum using specific proteases and RP-UHPLC-MS/MS. International Dairy Journal. 2021;119:104999. Available from: 10.1016/j.idairyj. 2021.104999.

6. Campione E, Cosio T, Rosa L, Lanna C, Girolamo SD, Gaziano R. Lactoferrin as protective natural barrier of respiratory and intestinal mucosa against coronavirus infection and inflammation. International Journal of Molecular Sciences. 2020;21(14):4903. Available from: 10.3390/ijms21144903.

7. Xiong L, Boeren S, Vervoort J, Hettinga K. Effect of milk serum proteins on aggregation, bacteriostatic activity and digestion of lactoferrin after heat treatment. Food Chemistry. 2021;337:127973. Available from: 10.1016/j.foodchem.2020. 127973.

8. Niaz B, Saeed F, Ahmed A, Imran M, Maan AA, Khan MK Lactoferrin (LF): a natural antimicrobial protein. International Journal of Food Properties. 2019;22(1):1626-41. Available from: 10.1080/10942912.2019.1666137. 
9. Woodman T, Strunk T, Patole S, Hartmann B, Simmer K, Currie $A$. Effects of lactoferrin on neonatal pathogens and Bifidobacterium breve in human breast milk. PLoS One. 2018;13(8):e0201819. Available from: 10.1371/journal.pone. 0201819.

10. Acosta-Smith $E$, Viveros-Jiménez $K$, Canizalez-Román $A$, Reyes-Lopez M, Bolscher JG, Nazmi K. Bovine lactoferrin and lactoferrin-derived peptides inhibit the growth of Vibrio cholerae and other Vibrio species. Frontiers in Microbiology. 2018;8:2633. Available from: 10.3389/fmicb.2017.02633.

11. Rascón-Cruz Q, Espinoza-Sánchez EA, Siqueiros-Cendón TS, Nakamura-Bencomo SI, Arévalo-Gallegos S, IglesiasFigueroa BF. Lactoferrin: A glycoprotein involved in immunomodulation, anticancer, and antimicrobial processes. Molecules (Basel, Switzerland). 2021;26(1):205. Available from: 10.3390/molecules26010205.

12. Bezault J, Bhimani R, Wiprovnick J, Furmanski P. Human lactoferrin inhibits growth of solid tumors and development of experimental metastases in mice. Cancer Research. 1994;54(9):2310-2.

13. Zhang J, Ling $\mathrm{T}, \mathrm{Wu} \mathrm{H}$, Wang $\mathrm{K}$. Re-expression of Lactotransferrin, a candidate tumor suppressor inactivated by promoter hypermethylation, impairs the malignance of oral squamous cell carcinoma cells. Journal of Oral Pathology \& Medicine. 2015;44(8):578-84. Available from: 10.1111/jop. 12279.

14. van der Strate BW, Beljaars L, Molema G, Harmsen MC, Meijer DK. Antiviral activities of lactoferrin. Antiviral Research. 2001;52(3):225-39. Available from: 10.1016/S0166-3542(01) 00195- 4 .

15. Elnagdy $S$, AlKhazindar M. The potential of antimicrobial peptides as an antiviral therapy against COVID-19. ACS Pharmacology \& Translational Science. 2020;3(4):780-2. Available from: 10.1021/acsptsci.0c00059.

16. Weimer KE, Roark H, Fisher $\mathrm{K}$, Cotten CM, Kaufman DA, Bidegain M. Breast milk and saliva lactoferrin levels and postnatal cytomegalovirus infection. American Journal of Perinatology. 2021;38(10):1070-7. Available from: 10.1055/s-00401701609.

17. Sultana C, Roşca A, Grancea C. In the backstage of lactoferrin derived peptides' antiviral activity. ROMANIAN ARCHIVES OF MICROBIOLOGY AND IMMUNOLOGY. 2018;77(3):213-21.

18. Ahmed KA, Saikat AS, Moni A, Kakon SA, Islam MR, Uddin MJ. Lactoferrin: potential functions, pharmacological insights, and therapeutic promises. J Adv Biotechnol Exp Ther. 2021;4(2):223. Available from: 10.5455/jabet.2021.d123

19. Wang $Y Z$, Zhao YQ, Wang YM, Zhao WH, Wang P, Chi CF. Antioxidant peptides from Antarctic Krill (Euphausia superba) hydrolysate: Preparation, identification and cytoprotection on $\mathrm{H} 2 \mathrm{O} 2$-induced oxidative stress. Journal of Functional Foods. 2021;86:104701. Available from: 10.1016/j.jff.2021.104701.

20. Zakharova ET, Sokolov AV, Pavlichenko NN, Kostevich VA, Abdurasulova IN, Chechushkov AV. Erythropoietin and Nrf2: key factors in the neuroprotection provided by apolactoferrin. Biometals. 2018;31(3):425-43. Available from: 10.1007/s10534-018-0111-9.

21. Rezaeimanesh N, Farzi N, Pirmanesh S, Emami S, Yadegar A Management of multi-drug resistant Helicobacter pylori infection by supplementary, complementary and alternative medicine; a review. Gastroenterology and Hepatology from Bed To Bench. 2017;10:8-14

22. Farid AS, Shemy MAE, Nafie E, Hegazy AM, Abdelhiee EY. Anti-inflammatory, anti-oxidant and hepatoprotective effects of lactoferrin in rats. Drug and Chemical Toxicology. 2021;44(3):286-93. Available from: 10.1080/01480545.2019. 1585868.

23. Goulding DA, Vidal K, Bovetto L, O'Regan J, O'Brien NM, O'Mahony JA. The impact of thermal processing on the simulated infant gastrointestinal digestion, bactericidal and anti-inflammatory activity of bovine lactoferrin - An in vitro study. Food Chemistry. 2021;362:130142. Available from: 10.1016/j.foodchem.2021.130142.

24. Chang R, Ng TB, Sun WZ. Lactoferrin as potential preventative and adjunct treatment for COVID-19. International Journal of Antimicrobial Agents. 2020;56(3):106118. Available from: 10.1016/j.ijantimicag.2020.106118.

25. Wang $Y$, Wang $P$, Wang $H$, Luo $Y$, Wan L, Jiang $M$. Lactoferrin for the treatment of COVID-19 (Review). Experimental and Therapeutic Medicine. 2020;20(6):272. Available from: 10.3892/etm.2020.9402.

26. Mann JK, Ndung'u T. The potential of lactoferrin, ovotransferrin and lysozyme as antiviral and immune-modulating agents in COVID-19. Future Virology. 2020;15(9):609-24. Available from: 10.2217/fvl-2020-0170.

27. Alpogan O, Karakucuk S. Lactoferrin: The Natural Protector of the Eye against Coronavirus-19. Ocular Immunology and Inflammation. 2021;29(4):751-2. Available from: 10.1080/09273948.2021.1954202.

28. Kondapi AK. Targeting cancer with lactoferrin nanoparticles: recent advances. Nanomedicine (London). 2020;15(21):2071-83. Available from: 10.2217/nnm-2020-0090.

29. Haridas M, Anderson BF, Baker EN. Structure of human diferric lactoferrin refined at 2.2 A resolution. Acta Crystallographica Section D, Biological Crystallography. 1995;51(Pt 5):629-46. Available from: 10.1107/S0907444994013521.

30. Wang M, Xu J, Han T, Tang L. Effects of theaflavins on the structure and function of bovine lactoferrin. Food Chemistry. 2021;338:128048. Available from: 10.1016/j.foodchem.2020. 128048.

31. Parc AL, Karav S, Rouquié C, Maga EA, Bunyatratchata A, Barile $\mathrm{D}$. Characterization of recombinant human lactoferrin $\mathrm{N}$ glycans expressed in the milk of transgenic cows. PLoS One. 2017;12(2):e0171477. Available from: 10.1371/journal.pone. 0171477.

32. Spik G, Coddeville B, Mazurier J, Bourne Y, Cambillaut $C$ Montreuil J. Primary and three-dimensional structure of lactotransferrin (lactoferrin) glycans. Lactoferrin. Springer; 1994:21-32.;. Available from: 10.1007/978-1-4615-2548-6_3.

33. Zlatina K, Galuska SP. The N-glycans of lactoferrin: more than just a sweet decoration. Biochemistry and Cell Biology. 2021;99(1):117-27. Available from: 10.1139/bcb-2020-0106.

34. Soboleva SE, Sedykh SE, Alinovskaya LI, Buneva VN, Nevinsky GA. Cow milk lactoferrin possesses several catalytic activities. Biomolecules. 2019;9(6):208. Available from: 10.3390/ biom9060208.

35. Steijns JM, van Hooijdonk AC. Occurrence, structure, biochemical properties and technological characteristics of lactoferrin. British Journal of Nutrition. 2000;84(S1):11-7. Available from: 10.1017/S0007114500002191.

36. Singh A, Ahmad N, Varadarajan A, Vikram N, Singh TP, Sharma S. Lactoferrin, a potential iron-chelator as an adjunct treatment for mucormycosis - A comprehensive review. International Journal of Biological Macromolecules. 2021;187:988-98. Available from: 10.1016/j.ijbiomac.2021. 07.156.

37. Omar OM, Assem H, Ahmed D, Elmaksoud MSA. Lactoferrin versus iron hydroxide polymaltose complex for the treatment of iron deficiency anemia in children with cerebral palsy: a randomized controlled trial. European Journal of Pediatrics. 2021;180(8):2609-18. Available from: 10.1007/ s00431-021-04125-9.

38. Cutone A, Colella B, Pagliaro A, Rosa L, Lepanto MS, di Patti $M C B$. Native and iron-saturated bovine lactoferrin differently hinder migration in a model of human glioblastoma by reverting epithelial-to-mesenchymal transition-like process and inhibiting interleukin-6/STAT3 axis. Cellular Signalling. 2020;65:109461. Available from: 10.1016/j.cellsig. 2019.109461.

39. Superti F. Lactoferrin from bovine milk: a protective companion for life. Nutrients. 2020;12(9):2562. Available from: 10.3390/nu12092562. 
40. Ward PP, Zhou X, Conneely OM. Cooperative interactions between the amino- and carboxyl-terminal lobes contribute to the unique iron-binding stability of lactoferrin. The Journal of Biological Chemistry. 1996;271(22):12790-4. Available from: $10.1074 / j b c .271 .22 .12790$.

41. Legrand D, van Berkel PH, Salmon V, van Veen HA, Slomianny MC, Nuijens JH. The N-terminal Arg2, Arg3 and Arg4 of human lactoferrin interact with sulphated molecules but not with the receptor present on Jurkat human lymphoblastic Tcells. The Biochemical Journal. 1997;327(Pt 3):841-6. Available from: 10.1042/bj3270841.

42. Rosa L, Cutone A, Lepanto MS, Scotti MJ, Conte MP, Paesano R. Physico-chemical properties influence the functions and efficacy of commercial bovine lactoferrins. Biometals. 2018;31(3):301-12. Available from: 10.1007/s10534-0180092-8.

43. Rosa L, Cutone A, Lepanto MS, Paesano R, Valenti P. Lactoferrin: a natural glycoprotein involved in iron and inflammatory homeostasis. International Journal of Molecular Sciences. 2017;18(9):1985. Available from: 10.3390/ijms18091985.

44. Mallaki M, Hosseinkhani A, Taghizadeh A, Hamidian G, Paya $\mathrm{H}$. The Effect of Bovine Lactoferrin and Probiotic on Performance and Health Status of Ghezel Lambs in Preweaning Phase. Iranian Journal of Applied Animal Science. 2021;11(1):101-10.

45. Preeti JKR, Suman M, Kannegundla U, Thakur M, Kumar R. A multifunctional bioactive protein: Lactoferrin. The Pharma Innovation Journal. 2018;7(4):7579. Available from: https://www.thepharmajournal.com/ archives/2018/vol7issue4/PartB/7-3-68-798.pdf.

46. van Berkel $\mathrm{PH}$, Geerts $M E$, van Veen $H A$, Mericskay $M$, de Boer $\mathrm{HA}$, Nuijens JH. N-terminal stretch Arg2, Arg3, Arg4 and Arg5 of human lactoferrin is essential for binding to heparin, bacterial lipopolysaccharide, human lysozyme and DNA. The Biochemical Journal. 1997;328(Pt 1):145-51. Available from: 10.1042/bj3280145.

47. Drago-Serrano ME, Campos-Rodriguez R, Carrero JC, de la Garza M. Lactoferrin and peptide-derivatives: antimicrobial agents with potential use in nonspecific immunity modulation. Current Pharmaceutical Design. 2018;24(10):1067-78. Available from: $10.2174 / 1381612824666180327155929$.

48. Li YQ, Guo C. A Review on Lactoferrin and Central Nervous System Diseases. Cells. 2021;10(7):1810. Available from: 10. 3390/cells10071810.

49. Giansanti F, Panella G, Arienzo A, Leboffe L, Antonini G. Nutraceutical peptides from lactoferrin. Journal of Advances in Dairy Research. 2018;6(1):199. Available from: 10.4172/2329888X.1000199.

50. Trovero MF, Scavone P, Platero R, de Souza EM, Fabiano E, Rosconi F. Herbaspirillum seropedicae differentially expressed genes in response to iron availability. Frontiers in Microbiology. 2018;9:1430. Available from: 10.3389/fmicb. 2018.01430.

51. Zhang Y, Pu C, Tang W, Wang S, Sun Q. Gallic acid liposomes decorated with lactoferrin: Characterization, in vitro digestion and antibacterial activity. Food Chemistry. 2019;293:315-22. Available from: 10.1016/j.foodchem.2019. 04.116.

52. Sun C, Li Y, Cao S, Wang H, Jiang C, Pang S. Antibacterial activity and mechanism of action of bovine lactoferricin derivatives with symmetrical amino acid sequences. International Journal of Molecular Sciences. 2018;19(10):2951. Available from: 10.3390/ijms19102951.

53. Liu ZS, Lin CF, Lee CP, Hsieh MC, Lu HF, Chen YF. A Single Plasmid of Nisin-Controlled Bovine and Human Lactoferrin Expressing Elevated Antibacterial Activity of LactoferrinResistant Probiotic Strains. Antibiotics (Basel, Switzerland). 2021;10(2):120. Available from: 10.3390/antibiotics10020120.

54. Mahdi L, Mahdi N, Al-Kakei S, Musafer H, Al-Joofy I, Essa R. Treatment strategy by lactoperoxidase and lactoferrin combination: immunomodulatory and antibacterial activity against multidrug-resistant Acinetobacter baumannii. Mi- crobial Pathogenesis. 2018;114:147-52. Available from: 10. 1016/j.micpath.2017.10.056.

55. Alhalwani AY, Davey RL, Kaul N, Barbee SA, Huffman JA Modification of lactoferrin by peroxynitrite reduces its antibacterial activity and changes protein structure. Proteins. 2020;88(1):166-74. Available from: 10.1002/prot.25782.

56. Haug BE, Svendsen JS. The role of tryptophan in the antibacterial activity of a 15-residue bovine lactoferricin peptide. Journal of Peptide Science. 2001;7(4):190-6. Available from: $10.1002 /$ psc.318.

57. Ramamourthy G, Vogel HJ. Antibiofilm activity of lactoferrinderived synthetic peptides against Pseudomonas aeruginosa PAO1. Biochemistry and Cell Biology. 2021;99(1):13848. Available from: $10.1139 / \mathrm{bcb}-2020-0253$

58. Str $\varnothing \mathrm{m} M B$, Rekdal $O$, Svendsen JS. Antibacterial activity of 15-residue lactoferricin derivatives. The Journal of Peptide Research. 2000;56(5):265-74. Available from: 10.1034/j. 1399-3011.2000.00770.x.

59. Chaparro SCV, Salguero JTV, Baquero DAM, Pérez JER. Effect of polyvalence on the antibacterial activity of a synthetic peptide derived from bovine lactoferricin against healthcare-associated infectious pathogens. BioMed Research International. 2018;2018:5252891. PMID: 29984236. Available from: 10.1155/2018/5252891.

60. Moreno-Expósito L, Illescas-Montes R, Melguizo-Rodríguez L, Ruiz C, Ramos-Torrecillas J, de Luna-Bertos E. Multifunctional capacity and therapeutic potential of lactoferrin. Life Sciences. 2018;195:61-4. Available from: 10.1016/j.lfs.2018. 01.002.

61. Sharma A, Shandilya UK, Sodhi M, Mohanty AK, Jain $P_{,}$ Mukesh M. Evaluation of Milk colostrum derived Lactoferrin of Sahiwal (Bos indicus) and Karan fries (cross-bred) cows for its anti-cancerous potential. International Journal of Molecular Sciences. 2019;20(24):6318. Available from: 10.3390/ijms20246318.

62. Sienkiewicz M, Jaśkiewicz A, Tarasiuk A, Fichna J. Lactoferrin: an overview of its main functions, immunomodulatory and antimicrobial role, and clinical significance. Critical Reviews in Food Science and Nutrition. 2021;p. 1-18. Available from: 10.1080/10408398.2021.1895063;Onlineaheadofprint.

63. Brinkmann V, Zychlinsky A. Beneficial suicide: why neutrophils die to make NETs. Nature Reviews Microbiology. 2007;5(8):577-82. Available from: 10.1038/nrmicro1710.

64. Vogel HJ. Lactoferrin, a bird's eye view. Biochemistry and Cell Biology. 2012;90(3):233-44. Available from: 10.1139/o2012016.

65. Kozu T, linuma G, Ohashi Y, Saito Y, Akasu T, Saito D. Effect of orally administered bovine lactoferrin on the growth of adenomatous colorectal polyps in a randomized, placebo-controlled clinical trial. Cancer Prevention Research (Philadelphia, Pa). 2009;2(11):975-83. Available from: 10 . 1158/1940-6207.CAPR-08-0208.

66. ligo M, Alexander DB, Xu J, Futakuchi M, Suzui M, Kozu T. Inhibition of intestinal polyp growth by oral ingestion of bovine lactoferrin and immune cells in the large intestine. Biometals. 2014;27(5):1017-29. Available from: 10.1007/s10534014-9747-2.

67. Cutone A, Rosa L, laniro G, Lepanto MS, di Patti MCB, Valenti P. Lactoferrin's anticancer properties: Safety, selectivity, and wide range of action. Biomolecules. 2020;10(3):456. Available from: 10.3390/biom10030456

68. Guedes JP, Pereira CS, Rodrigues LR, Côrte-Real M. Bovine milk lactoferrin selectively kills highly metastatic prostate cancer PC-3 and osteosarcoma MG-63 cells in vitro. Frontiers in Oncology. 2018;8:200. Available from: 10.3389/fonc.2018. 00200.

69. Pereira CS, Guedes JP, Gonçalves M, Loureiro L, Castro L, Gerós H. Lactoferrin selectively triggers apoptosis in highly metastatic breast cancer cells through inhibition of plasmalemmal V-H+-ATPase. Oncotarget. 2016;7(38):62144-58. Available from: 10.18632/oncotarget.11394. 
70. Kühnle A, Veelken R, Galuska CE, Saftenberger M, Verleih M, Schuppe HC. Polysialic acid interacts with lactoferrin and supports its activity to inhibit the release of neutrophil extracellular traps. Carbohydrate Polymers. 2019;208:32-41. Available from: 10.1016/j.carbpol.2018.12.033.

71. Jiang R, Lönnerdal B. Bovine lactoferrin and lactoferricin exert antitumor activities on human colorectal cancer cells (HT-29) by activating various signaling pathways. Biochemistry and Cell Biology. 2017;95(1):99-109. Available from: 10.1139/bcb-2016-0094.

72. Riedl S, Leber R, Rinner B, Schaider H, Lohner K, Zweytick $D$. Human lactoferricin derived di-peptides deploying loop structures induce apoptosis specifically in cancer cells through targeting membranous phosphatidylserine. Biochimica et Biophysica Acta. 2015;1848(11):2918-31. Available from: 10.1016/j.bbamem.2015.07.018.

73. Arias M, Hilchie AL, Haney EF, Bolscher JG, Hyndman ME, Hancock RE. Anticancer activities of bovine and human lactoferricin-derived peptides. Biochemistry and Cell Biology. 2017;95(1):91-8. Available from: 10.1139/bcb-20160175.

74. Taha S, Mokbel S, Abdel-Hamid M, Hamed A. Antiviral activity of lactoferrin against Potato virus times in vitro and in vivo. International Journal of Dairy Science. 2015;10(2):8694. Available from: 10.3923/ijds.2015.86.94.

75. Oda H, Kolawole AO, Mirabelli C, Wakabayashi H, Tanaka M, Yamauchi K. Antiviral effects of bovine lactoferrin on human norovirus. Biochemistry and Cell Biology. 2021;99(1):166-72. Available from: $10.1139 / \mathrm{bcb}-2020-0035$.

76. Malaczewska J, Kaczorek-Lukowska E, Wójcik R, Siwicki AK Antiviral effects of nisin, lysozyme, lactoferrin and their mixtures against bovine viral diarrhoea virus. BMC Veterinary Research. 2019;15(1):318. Available from: 10.1186/s12917019-2067-6.

77. Lu L, Hangoc G, Oliff A, Chen LT, Shen RN, Broxmeyer HE. Protective influence of lactoferrin on mice infected with the polycythemia-inducing strain of Friend virus complex. Cancer Research. 1987;47(15):4184-8.

78. Fujihara T, Hayashi K. Lactoferrin inhibits herpes simplex virus type-1 (HSV-1) infection to mouse cornea. Archives of Virology. 1995;140(8):1469-72. Available from: 10.1007/ BF01322673.

79. Shimizu K, Matsuzawa H, Okada K, Tazume S, Dosako $S$, Kawasaki Y. Lactoferrin-mediated protection of the host from murine cytomegalovirus infection by a T-celldependent augmentation of natural killer cell activity. Archives of Virology. 1996;141(10):1875-89. Available from: 10.1007/BF01718201.

80. Tanaka K, Ikeda M, Nozaki A, Kato N, Tsuda H, Saito S. Lactoferrin inhibits hepatitis $C$ virus viremia in patients with chronic hepatitis $\mathrm{C}$ : a pilot study. Japanese Journal of Cancer Research. 1999;90(4):367-71. Available from: 10.1111/j. 1349-7006.1999.tb00756.x

81. Iwasa M, Kaito M, Ikoma J, Takeo M, Imoto I, Adachi Y. Lactoferrin inhibits hepatitis $C$ virus viremia in chronic hepatitis $C$ patients with high viral loads and HCV genotype $1 \mathrm{~b}$. The American Journal of Gastroenterology. 2002;97(3):7667. Available from: $10.1111 / j .1572-0241.2002 .05573 . x$.

82. Orsi $\mathrm{N}$. The antimicrobial activity of lactoferrin: current status and perspectives. Biometals. 2004;17(3):189-96. Available from: 10.1023/B:BIOM.0000027691.86757.e2.

83. Hu $Y$, Meng $X$, Zhang $F$, Xiang $Y$, Wang J. The in vitro antiviral activity of lactoferrin against common human coronaviruses and SARS-CoV- 2 is mediated by targeting the heparan sulfate co-receptor. Emerging Microbes \& Infections. 2021;10(1):317-30. Available from: 10.1080/22221751.2021. 1888660.

84. Sinopoli A, Isonne C, Santoro MM, Baccolini V. The effects of orally administered lactoferrin in the prevention and management of viral infections: A systematic review. Reviews in Medical Virology. 2022;32(1):e2261. Available from: 10.1002/ rmv.2261.
85. Oda H, Wakabayashi H, Tanaka M, Yamauchi K, Sugita C, Yoshida $\mathrm{H}$. Effects of lactoferrin on infectious diseases in Japanese summer: A randomized, double-blinded, placebocontrolled trial. Journal of Microbiology, Immunology, and Infection. 2021;54(4):566-74. Available from: 10.1016/j.jmii. 2020.02.010.

86. Sano H, Nagai K, Tsutsumi H, Kuroki Y. Lactoferrin and surfactant protein $A$ exhibit distinct binding specificity to $F$ protein and differently modulate respiratory syncytial virus infection. European Journal of Immunology. 2003;33(10):2894902. Available from: 10.1002/eji.200324218.

87. Pietrantoni $A$, Biase AMD, Tinari A, Marchetti M, Valenti $P_{x}$ Seganti L. Bovine lactoferrin inhibits adenovirus infection by interacting with viral structural polypeptides. Antimicrobial Agents and Chemotherapy. 2003;47(8):2688-91. Available from: 10.1128/AAC.47.8.2688-2691.2003.

88. Lang J, Yang N, Deng J, Liu K, Yang P, Zhang G. Inhibition of SARS pseudovirus cell entry by lactoferrin binding to heparan sulfate proteoglycans. PLoS One. 2011;6(8):e23710. Available from: 10.1371/journal.pone.0023710.

89. Weng TY, Chen LC, Shyu HW, Chen SH, Wang JR, Yu CK. Lactoferrin inhibits enterovirus 71 infection by binding to VP1 protein and host cells. Antiviral Research. 2005;67(1):31-7. Available from: 10.1016/j.antiviral.2005.03.005.

90. Beljaars L, van der Strate BW, Bakker HI, Reker-Smit C, van Loenen-Weemaes AM, Wiegmans FC. Inhibition of cytomegalovirus infection by lactoferrin in vitro and in vivo. Antiviral Research. 2004;63(3):197-208. Available from: 10. 1016/j.antiviral.2004.05.002.

91. Ammendolia MG, Marchetti M, Superti F. Bovine lactoferrin prevents the entry and intercellular spread of herpes simplex virus type 1 in Green Monkey Kidney cells. Antiviral Research. 2007;76(3):252-62. Available from: 10.1016/j.antiviral.2007. 07.005 .

92. Malhotra JD, Kaufman RJ. Endoplasmic reticulum stress and oxidative stress: a vicious cycle or a double-edged sword? Antioxidants \& Redox Signaling. 2007;9(12):2277-93. Available from: 10.1089/ars.2007.1782.

93. Guo C, Xue H, Guo T, Zhang W, Xuan WQ, Ren YT, et al. Recombinant human lactoferrin attenuates the progression of hepatosteatosis and hepatocellular death by regulating iron and lipid homeostasis in ob/ob mice. Food \& Function. 2020;11(8):7183-96. Available from: 10.1039/D0FO00910E.

94. Yang $\mathrm{Y}, \mathrm{He} \mathrm{Y}, \mathrm{Jin} \mathrm{Y}, \mathrm{Wu} \mathrm{G}, \mathrm{Wu} Z$. Amino acids in endoplasmic reticulum stress and redox signaling. Amino Acids in Nutrition and Health. Springer; 2021:35-49;.

95. Kuhara T, Yamauchi K, Iwatsuki K. Bovine lactoferrin induces interleukin-11 production in a hepatitis mouse model and human intestinal myofibroblasts. European Journal of $\mathrm{Nu}$ trition. 2012;51(3):343-51. Available from: 10.1007/s00394011-0219-y.

96. Kong X, Yang M, Guo J, Feng Z. Effects of bovine lactoferrin on rat intestinal epithelial cells. Journal of Pediatric Gastroenterology and Nutrition. 2020;70(5):645-51. Available from: 10.1097/MPG.0000000000002636.

97. Tian H, Maddox IS, Ferguson LR, Shu Q. Evaluation of the cytoprotective effects of bovine lactoferrin against intestinal toxins using cellular model systems. Biometals. 2010;23(3):589-92. Available from: 10.1007/s10534-0109301-9.

98. Safaeian L, Javanmard SH, Mollanoori Y, Dana N. Cytoprotective and anti-oxidant effects of human lactoferrin against $\mathrm{H} 2 \mathrm{O} 2$-induced oxidative stress in human umbilical vein endothelial cells. Advanced Biomedical Research. 2015;:..:4.

99. Lepanto MS, Rosa L, Paesano R, Valenti P, Cutone A. Lactoferrin in aseptic and septic inflammation. Molecules (Basel, Switzerland). 2019;24(7):1323. Available from: 10.3390/ molecules24071323.

100. Kim SE, Choi S, Hong JY, Shim KS, Kim TH, Park K. Accelerated osteogenic differentiation of MC3T3-E1 cells by lactoferrin-conjugated nanodiamonds through enhanced 
anti-oxidant and anti-inflammatory effects. Nanomaterials (Basel, Switzerland). 2019;10(1):50. Available from: 10.3390/ nano10010050.

101. Hao L, Shan Q, Wei J, Ma F, Sun P. Lactoferrin: major physiological functions and applications. Current Protein \& Peptide Science. 2019;20(2):139-44. Available from: 10.2174/ 1389203719666180514150921.

102. Xu S, Wang F, Wang Y, Wang R, Hou K, Tian C. A silkworm based silk gland bioreactor for high-efficiency production of recombinant human lactoferrin with antibacterial and antiinflammatory activities. Journal of Biological Engineering. 2019;13(1):61. Available from: 10.1186/s13036-019-0186-z.

103. Choi HJ, Choi S, Kim JG, Song MH, Shim KS, Lim YM. Enhanced tendon restoration effects of anti-inflammatory, lactoferrin-immobilized, heparin-polymeric nanoparticles in an Achilles tendinitis rat model. Carbohydrate Polymers 2020;241:116284. Available from: 10.1016/j.carbpol.2020. 116284.

104. Puddu P, Latorre D, Carollo M, Catizone A, Ricci G, Valenti P. Bovine lactoferrin counteracts Toll-like receptor mediated activation signals in antigen presenting cells. PLoS One. 2011;6(7):e22504. Available from: 10.1371/journal. pone.0022504.

105. Rosa L, Lepanto MS, Cutone A, laniro G, Pernarella S, Sangermano R. Lactoferrin and oral pathologies: a therapeutic treatment. Biochemistry and Cell Biology. 2021;99(1):81-90. Available from: 10.1139/bcb-2020-0052.

106. Kell DB, Heyden EL, Pretorius E. The biology of lactoferrin, an iron-binding protein that can help defend against viruses and bacteria. Frontiers in Immunology. 2020;11:1221. Available from: 10.3389/fimmu.2020.01221.

107. Spear PG. Herpes simplex virus: receptors and ligands for cell entry. Cellular Microbiology. 2004;6(5):401-10. Available from: 10.1111/j.1462-5822.2004.00389.x.

108. Cagno V, Tseligka ED, Jones ST, Tapparel C. Heparan sulfate proteoglycans and viral attachment: true receptors or adaptation bias? Viruses. 2019;11(7):596. Available from: 10.3390/v11070596.

109. Sapp M, Bienkowska-Haba M. Viral entry mechanisms: human papillomavirus and a long journey from extracellular matrix to the nucleus. The FEBS Journal. 2009;276(24):720616. Available from: $10.1111 / j .1742-4658.2009 .07400$.x.

110. Nozaki A, Ikeda M, Naganuma A, Nakamura T, Inudoh M, Tanaka K. Identification of a lactoferrin-derived peptide possessing binding activity to hepatitis $C$ virus E2 envelope protein. The Journal of Biological Chemistry. 2003;278(12):10162-73. Available from: $10.1074 / \mathrm{jbc}$. M207879200.

111. Tominaga M, Caterina MJ, Malmberg AB, Rosen TA, Gilbert $H$, Skinner K. The cloned capsaicin receptor integrates multiple pain-producing stimuli. Neuron. 1998;21(3):531-43. Available from: 10.1016/S0896-6273(00)80564-4.

112. Kamhi E, Joo EJ, Dordick JS, Linhardt RJ. Glycosaminoglycans in infectious disease. Biological Reviews of the Cambridge Philosophical Society. 2013;88(4):928-43. Available from: 10. 1111/brv.12034

113. Bernard KA, Klimstra WB, Johnston RE. Mutations in the E2 glycoprotein of Venezuelan equine encephalitis virus confer heparan sulfate interaction, low morbidity, and rapid clearance from blood of mice. Virology. 2000;276(1):93-103. Available from: 10.1006/viro.2000.0546.

114. Goodfellow IG, Sioofy AB, Powell RM, Evans DJ. Echoviruses bind heparan sulfate at the cell surface. Journal of Virology. 2001;75(10):4918-21. Available from: 10.1128/JVI.75. 10.4918-4921.2001.

115. Li P, Sheng J, Liu Y, Li J, Liu J, Wang F. Heparosan-derived heparan sulfate/heparin-like compounds: one kind of potential therapeutic agents. Medicinal Research Reviews. 2013;33(3):665-92. Available from: 10.1002/med.21263.

116. Zheng J. SARS-CoV-2: an emerging coronavirus that causes a global threat. International Journal of Biological Sciences. 2020;16(10):1678-85. Available from: 10.7150/ijbs.45053.
117. Belting $M$. Heparan sulfate proteoglycan as a plasma membrane carrier. Trends in Biochemical Sciences. 2003;28(3):145-51. Available from: 10.1016/S0968-0004(03) 00031-8.

118. Carvalho CA, Sousa IP, Silva JL, Oliveira AC, Gonçalves RB, Gomes AM. Inhibition of Mayaro virus infection by bovine lactoferrin. Virology. 2014;452-453:297-302. Available from: 10.1016/j.virol.2014.01.022.

119. Jenssen $H$, Hancock RE. Antimicrobial properties of lactoferrin. Biochimie. 2009;91(1):19-29. Available from: 10.1016/j. biochi.2008.05.015.

120. Yan R, Zhang Y, Li Y, Xia L, Guo Y, Zhou Q. Structural basis for the recognition of SARS-CoV-2 by full-length human ACE2. Science. 2020;367(6485):1444-8. Available from: $10.1126 /$ science.abb2762.

121. Gao C, Zeng J, Jia N, et al. SARS-CoV-2 Spike protein interacts with multiple innate immune receptors. bioRxiv. Preprint at https://doi org/101101/202007. 2020;29;.

122. Han DP, Lohani M, Cho MW. Specific asparagine-linked glycosylation sites are critical for DC-SIGN- and L-SIGNmediated severe acute respiratory syndrome coronavirus entry. Journal of Virology. 2007;81(21):12029-39. Available from: 10.1128/JVI.00315-07.

123. Chen JM, Fan YC, Lin JW, Chen YY, Hsu WL, Chiou SS. Bovine lactoferrin inhibits dengue virus infectivity by interacting with heparan sulfate, low-density lipoprotein receptor, and DC-SIGN. International Journal of Molecular Sciences. 2017;18(9):1957. Available from: 10.3390/ijms18091957.

124. Ahlawat S, Asha, Sharma KK. Immunological co-ordination between gut and lungs in SARS-CoV-2 infection. Virus Research. 2020;286:198103. Available from: 10.1016/j.virusres. 2020.198103.

125. Dai YJ, Hu F, Li H, Huang HY, Wang DW, Liang Y. A profiling analysis on the receptor ACE2 expression reveals the potential risk of different type of cancers vulnerable to SARS-CoV2 infection. Annals of Translational Medicine. 2020;8(7):481. Available from: 10.21037/atm.2020.03.61.

126. Yeo C, Kaushal S, Yeo D. Enteric involvement of coronaviruses: is faecal-oral transmission of SARS-CoV-2 possible? The Lancet Gastroenterology \& Hepatology. 2020;5(4):3357. Available from: 10.1016/S2468-1253(20)30048-0.

127. Fenouillet $E$, Barbouche R, Jones IM. Cell entry by enveloped viruses: redox considerations for HIV and SARS-coronavirus. Antioxidants \& Redox Signaling. 2007;9(8):1009-34. Available from: 10.1089/ars.2007.1639.

128. Wakabayashi $\mathrm{H}$, Oda H, Yamauchi K, Abe F. Lactoferrin for prevention of common viral infections. Journal of Infection and Chemotherapy. 2014;20(11):666-71. Available from: 10. 1016/j.jiac.2014.08.003.

129. Freitas AR, Donalisio MR. Respiratory syncytial virus seasonality in Brazil: implications for the immunisation policy for at-risk populations. Memorias do Instituto Oswaldo Cruz. 2016;111(5):294-301. Available from: 10.1590/007402760150341.

130. González-Chávez SA Arévalo-Gallegos S, Rascón-Cruz Q. actoferrin: structure, function and applications. International journal of antimicrobial agents. 2009;33(4):e1-e8. Available from: 10.1016/j.ijantimicag.2008.07.020.

131. Redwan EM, Uversky VN, El-Fakharany EM, Al-Mehdar H. Potential lactoferrin activity against pathogenic viruses. Comptes Rendus Biologies. 2014;337(10):581-95. Available from: 10.1016/j.crvi.2014.08.003.

132. Berlutti F, Pantanella F, Natalizi T, Frioni A, Paesano $R$, Polimeni $A$, et al. Antiviral properties of lactoferrin: a natural immunity molecule. Molecules (Basel, Switzerland). 2011;16(8):6992-7018. Available from: 10.3390/ molecules 16086992.

133. Legrand D, Elass E, Carpentier M, Mazurier J. Lactoferrin: a modulator of immune and inflammatory responses. Cellular and Molecular Life Sciences. 2005;62(22):2549-59. Available from: 10.1007/s00018-005-5370-2. 
134. Peroni DG, Fanos V. Lactoferrin is an important factor when breastfeeding and COVID-19 are considered. Acta Paediatrica (Oslo, Norway: 1992). 2020;2020. Available from: 10. 1111/apa.15417.

135. Clausen TM, Sandoval DR, Spliid CB, et al. SARS-CoV-2 infection depends on cellular heparan sulfate and ACE2. Cell. 2020;183(4):1043-1057. e15. Available from: 10.1016/j.cell. 2020.09 .033 .

136. Milewska A, Zarebski M, Nowak P, Stozek K, Potempa J, Pyrc K. Human coronavirus NL63 utilizes heparan sulfate proteoglycans for attachment to target cells. Journal of Virology. 2014;88(22):13221-30. Available from: 10.1128/JVI.0207814.

137. Ou X, Liu Y, Lei $X$, Li $P$, Mi D, Ren L. Characterization of spike glycoprotein of SARS-CoV-2 on virus entry and its immune cross-reactivity with SARS-CoV. Nature Communications. 2020;11(1):1620. Available from: 10.1038/s41467-02015562-9.

138. Pišlar A, Mitrović A, Sabotivc J, Fonović UP, Nanut MP, Jakoš $\mathrm{T}$, et al. The role of cysteine peptidases in coronavirus cell entry and replication: the therapeutic potential of cathepsin inhibitors. PLoS Pathogens. 2020;16(11):e1009013. Available from: 10.1371/journal.ppat.1009013.

139. Sano E, Miyauchi R, Takakura N, Yamauchi K, Murata E, Le QT. Cysteine protease inhibitors in various milk preparations and its importance as a food. Food Research International. 2005;38(4):427-33. Available from: 10.1016/j.foodres.2004. 10.011

140. Crawford KH, Eguia R, Dingens AS, Loes AN, Malone KD, Wolf $\mathrm{CR}$. Protocol and reagents for pseudotyping lentiviral particles with SARS-CoV-2 spike protein for neutralization assays. Viruses. 2020;12(5):513. Available from: 10.3390/v12050513.

141. Nie J, Li Q, Wu J, Zhao C, Hao H, Liu H, et al. Establishment and validation of a pseudovirus neutralization assay for SARSCoV-2. Emerging Microbes \& Infections. 2020;9(1):680-6. Available from: 10.1080/22221751.2020.1743767.

142. Hoffmann M, Kleine-Weber $\mathrm{H}$, Schroeder S, et al. SARS-CoV-2 cell entry depends on ACE2 and TMPRSS2 and is blocked by a clinically proven protease inhibitor. Cell. 2020;181(2):271280. e8. PMID: 32142651 . Available from: 10.1016/j.cell.2020. 02.052

143. Shang J, Wan Y, Luo C, Ye G, Geng Q, Auerbach A. Cell entry mechanisms of SARS-CoV-2. Proceedings of the National Academy of Sciences of the United States of America. 2020;117(21):11727-34. Available from: 10.1073/pnas. 2003138117.

144. Kong Q, Xiang Z, Wu Y, Gu Y, Guo J, Geng F. Analysis of the susceptibility of lung cancer patients to SARS-CoV-2 infection. Molecular Cancer. 2020;19(1):80. Available from: 10.1186/s12943-020-01209-2.

145. Naskalska A, Dabrowska A, Szczepanski A, Milewska A, Jasik KP, Pyrc K. Membrane protein of human coronavirus NL63 is responsible for interaction with the adhesion receptor. Journal of Virology. 2019;93(19):e00355-19. Available from: 10.1128/JVI.00355-19.

146. Niesen FH, Berglund $H$, Vedadi M. The use of differential scanning fluorimetry to detect ligand interactions that promote protein stability. Nature Protocols. 2007;2(9):2212-21. Available from: 10.1038/nprot.2007.321.

147. Tso FY, Lidenge SJ, Peña PB, Clegg AA, Ngowi JR, Mwaiselage J. High prevalence of pre-existing serological cross-reactivity against severe acute respiratory syndrome coronavirus- 2
(SARS-CoV-2) in sub-Saharan Africa. International Journal of Infectious Diseases. 2021;102:577-83. Available from: 10.1016/j.ijid.2020.10.104.

148. Campione E, Lanna C, Cosio T, Rosa L, Conte MP, lacovelli F. Lactoferrin against SARS-CoV-2: in vitro and in silico evidences. Frontiers in Pharmacology. 2021;12:666600. Available from: 10.3389/fphar.2021.666600.

149. Elfiky AA. Ribavirin, Remdesivir, Sofosbuvir, Galidesivir, and Tenofovir against SARS-CoV-2 RNA dependent RNA polymerase (RdRp): A molecular docking study. Life Sciences. 2020;253:117592. Available from: 10.1016/j.lfs.2020.117592.

150. Chitranshi N, Gupta VK, Rajput R, Godinez A, Pushpitha K Shen T. Evolving geographic diversity in SARS-CoV2 and in silico analysis of replicating enzyme $3 C L$ pro targeting repurposed drug candidates. Journal of Translational Medicine. 2020;18(1):278. Available from: 10.1186/s12967-020-02448-

151. Mokhtari RB, Homayouni TS, Baluch N, Morgatskaya E, Kumar S, Das B. Combination therapy in combating cancer. Oncotarget. 2017;8(23):38022-43. Available from: 10.18632/ oncotarget.16723.

152. van der Pluijm RW, Tripura R, Hoglund RM, Phyo AP, Lek $D$, Islam AU, et al. Triple artemisinin-based combination therapies versus artemisinin-based combination therapies for uncomplicated Plasmodium falciparum malaria: a multicentre, open-label, randomised clinical trial. Lancet. 2020;395(10233):1345-60. Available from: 10.1016/S01406736(20)30552-3.

153. Ma C, Hu Y, Zhang J, Wang J. Pharmacological characterization of the mechanism of action of R523062, a promising antiviral for enterovirus D68. ACS Infectious Diseases. 2020;6(8):2260-70. Available from: 10.1021/acsinfecdis. $0 \mathrm{c} 00383$.

154. Cox MJ, Loman N, Bogaert D, O'Grady J. Co-infections: potentially lethal and unexplored in COVID-19. The Lancet Microbe. 2020;1(1):e11. Available from: 10.1016/S26665247(20)30009-4.

155. Abeyrathne ED, Huang $X, A$ hn DU. Antioxidant, angiotensinconverting enzyme inhibitory activity and other functional properties of egg white proteins and their derived peptides A review. Poultry Science. 2018;97(4):1462-8. Available from: $10.3382 / \mathrm{ps} / \mathrm{pex} 399$

156. Nimalaratne C, Bandara N, Wu J. Purification and characterization of antioxidant peptides from enzymatically hydrolyzed chicken egg white. Food Chemistry. 2015;188:46772. Available from: 10.1016/j.foodchem.2015.05.014.

157. Rainard P. Activation of the classical pathway of complement by binding of bovine lactoferrin to unencapsulated Streptococcus agalactiae. Immunology. 1993;79(4):648-52.

158. Stephens S, Dolby JM, Montreuil J, Spik G. Differences in inhibition of the growth of commensal and enteropathogenic strains of Escherichia coli by lactotransferrin and secretory immunoglobulin A isolated from human milk. Immunology. 1980;41(3):597-603.

159. Marks DJ, Harbord MW, MacAllister R, Rahman FZ, Young J, Al-Lazikani B. Defective acute inflammation in Crohn's disease: a clinical investigation. Lancet. 2006;367(9511):66878. Available from: 10.1016/S0140-6736(06)68265-2.

160. Algahtani FD, Elabbasy MT, Samak MA, Adeboye AA, Yusuf RA, Ghoniem ME. The Prospect of Lactoferrin Use as Adjunctive Agent in Management of SARS-CoV-2 Patients: A Randomized Pilot Study. Medicina (Kaunas, Lithuania). 2021;57(8):842. Available from: 10.3390/medicina57080842. 
Ready to submit your manuscript? Choose Biomedpress and benefit from:

- Fast, convenient online submission

- Through peer-review by experienced researchers

- Rapid publication on acceptance

- Free of charge (without publication fees)

Learn more http://www.biomedpress.org/journals/
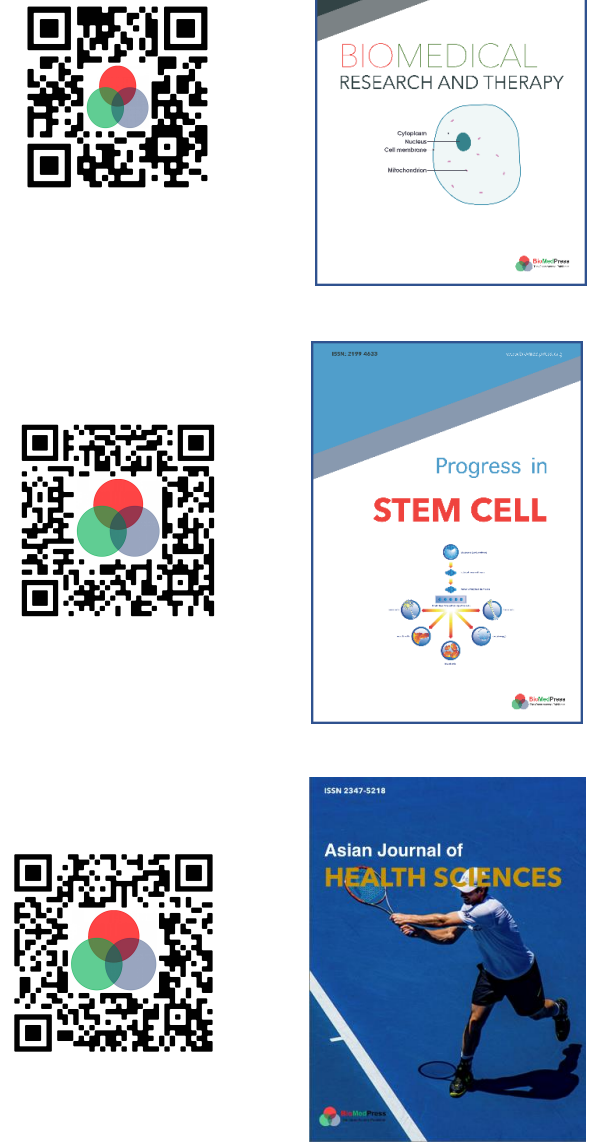

Asian Journal of Health Sciences

ISSN: 2347-5218

Indexed: Google Scholar

Acceptance Rate (2020): 72.89\%

Article Publishing Charge: Free

Submission to first editorial decision: 16.5 days

Biotechnological Research

ISSN: 2395-6763

Indexed: Google Scholar

Acceptance Rate (2020): $67.02 \%$

Article Publishing Charge: Free

Submission to first editorial decision: 28.5 days 